\title{
Comparing ECMWF AOD with AERONET observations at visible and $U V$ wavelengths
}

\author{
V. Cesnulyte ${ }^{1,2}$, A. V. Lindfors ${ }^{1}$, M. R. A. Pitkänen ${ }^{1,2}$, K. E. J. Lehtinen ${ }^{1,2}$, J.-J. Morcrette ${ }^{3}$, and A. Arola ${ }^{1}$ \\ ${ }^{1}$ Finnish Meteorological Institute, Kuopio, Finland \\ ${ }^{2}$ Department of Applied Physics, University of Eastern Finland, Kuopio, Finland \\ ${ }^{3}$ European Centre for Medium-Range Weather Forecasts, Reading, UK
}

Correspondence to: V. Cesnulyte (vaida.cesnulyte@fmi.fi)

Received: 22 May 2013 - Published in Atmos. Chem. Phys. Discuss.: 26 July 2013

Revised: 10 December 2013 - Accepted: 12 December 2013 - Published: 21 January 2014

\begin{abstract}
This paper presents validation results of the European Centre for Medium-Range Weather Forecasts (ECMWF) Integrated Forecasting System MACC (Monitoring Atmospheric Composition and Climate) re-analysis aerosol optical depth (AOD) for the period 2003-2006. We evaluate the MACC AOD at a UV wavelength $(340 \mathrm{~nm})$ and at mid-visible $(500$ and $550 \mathrm{~nm}$ ) by comparing against ground-based AERONET measurements at 12 sites. The AERONET sites cover various parts of the globe and are categorized in three groups: urban/anthropogenic, biomass burning and dust, depending on the typically dominating aerosol type. This is the first time a global model such as the ECMWF has been evaluated for the performance of AOD at a UV wavelength. The results show that the MACC system generally provides a good representation of the AOD on a monthly basis, showing a realistic seasonal cycle. The model is mostly able to capture major dust load events and also the peak months of biomass burning correctly. For Kanpur and Solar Village, however, the model overestimates the AOD during the monsoon period when the aerosol load is generally low. When comparing hourly AOD values, the modelmeasurement agreement is better for biomass burning and dust sites than for urban sites, with an average correlation coefficient around 0.90 for biomass burning sites, around 0.77 for dust sites, and below 0.70 for urban sites. The AOD at $500 \mathrm{~nm}$ averaged over all sites shows only a small systematic difference between modeled and measured values, with a relative mean bias of 0.02 . However, for the AOD at $340 \mathrm{~nm}$ the relative mean bias is -0.2 . All sites included in the study show a relative mean bias at $340 \mathrm{~nm}$ smaller (or more negative) than that at $500 \mathrm{~nm}$, indicating a strong wavelength
\end{abstract}

dependence in the performance of the AOD in the MACC system. A comparison against fine and coarse mode AOD of the AERONET indicates that this has to do with the size distribution of the model: generally, the ECMWF model overestimates the contribution by coarse mode particles.

\section{Introduction}

The European Centre for Medium-Range Weather Forecasts (ECMWF) is one of the main weather forecasting models, providing high-resolution global weather forecasts up to 10 days, ensemble prediction system forecasts up to 30 days, and seasonal forecasts for up to 12 months. Since 1989 the effects of aerosols, as a part of its radiation transfer calculations, have been included in the model (Morcrette et al., 2009). Recently, Morcrette et al. (2009) and Benedetti et al. (2009) developed an aerosol data assimilation system within the ECMWF Integrated Forecast System (IFS) including prognostic aerosols: sea salt, desert dust, organic matter, black carbon, and sulfate aerosols, which are advected by the model dynamics and interact with the model physics. Within the European Framework Programme 7 MACC (Monitoring Atmospheric Composition and Climate) and MACC-II projects, this system has provided a re-analysis of greenhouse gases, reactive gases and aerosols covering 20032006, and now provides an ongoing analysis. The MACC products currently are not officially ECMWF products, however, in this paper ECMWF and MACC are used interchangeably. 
Few previous studies have been done looking into the performance of the ECMWF aerosol model by comparing the model data against satellite and AErosol RObotic NETwork (AERONET) data. Morcrette et al. (2009) focused on a comparison of monthly mean and daily aerosol quantities, like aerosol optical depth (AOD), at $550 \mathrm{~nm}$ against satellite and surface observations at various locations. Morcrette et al. (2009) found that the ECMWF model agrees well with satellite and ground-based measurements in areas where sea salt and dust aerosols dominate. Another study by Mangold et al. (2011) focused on different case studies, such as a summer heat wave in Europe in 2003, a Saharan dust event in 2004, and events with high and low sea-salt aerosol load. Mangold et al. (2011) draw several main conclusions: (1) the Saharan dust storm analysis demonstrated that transport and atmospheric dynamics were simulated reasonably well in the model; (2) during the period of the european summer heat wave in 2003, the aerosol model captured the distinct increase of sulfate mass concentration very well. However, the model overestimated the observed sulfate mass concentration; (3) with respect to the total AOD predictions during the summer heat wave period, the aerosol model matched well the observed overall AOD level and day-to-day variability, although the model missed or underestimated some peaks.

Both Morcrette et al. (2009) and Mangold et al. (2011) concentrated on mid-visible AOD. However, the ECMWF radiative transfer scheme has recently been extended to also include UV wavelengths (Morcrette and Arola, 2007). As the radiative effect of aerosols generally increase towards shorter wavelengths, a better understanding of the performance of the ECMWF AOD at UV wavelengths is a prerequisite for understanding the behavior of the UV radiation in the model.

The aim of the present study is to continue and extend upon the work started by Morcrette et al. (2009) and Mangold et al. (2011) by comparing the MACC re-analysis data with ground-based AOD measurements from 12 AERONET sites representing different aerosol environments. Our main emphasis is on AOD in the UV band $(340 \mathrm{~nm})$, but we also include the AOD at other wavelengths $(500$ and $550 \mathrm{~nm})$ in order to examine possible wavelength-dependent features.

\section{Methods and data}

\subsection{MACC aerosol re-analysis}

In this study we compare forecasted aerosol fields from the ECMWF Integrated Forecasting System (IFS) over the period 2003-2006 with corresponding AERONET AOD measurements. We used the hourly AOD forecast values from MACC re-analysis fdmj data set. To cover a full day of AOD values, we took hourly forecast AOD from timesteps 1 to $12 \mathrm{~h}$ from forecast base times 00:00 UTC and 12:00 UTC.

The ECMWF IFS will be shortly described below based on Morcrette et al. (2009) and Benedetti et al. (2009). The
ECMWF IFS uses external data of aerosol optical depth at $550 \mathrm{~nm}$ retrieved from MODIS (Level 2, collection 5) instruments on board of Terra and Aqua satellites, which are assimilated into the model. MODIS data are chosen for their reliability and availability in near-real time. General description of MODIS AOD over land is given by Levy et al. (2007a, b), and over ocean by Remer et al. (2005, 2008). However, over highly reflective surfaces, such as deserts and snow covered areas, there is no sufficient contrast to discern the aerosol signal, and therefore, no MODIS AOD data exist over such areas. No so-called DeepBlue data (Hsu et al., 2006) are used in this re-analysis. The emission sources for the various aerosol species are defined either using established emission inventories or through parametrization. The model includes prognostic variables for the mass of sea salt (SS), desert dust (DU), organic matter (OM), black carbon (BC), and sulfate aerosols $\left(\mathrm{SO}_{4}\right)$, interactive with both the dynamics and physics of the model. The SS and DU have their sources linked to prognostic and diagnostic surface and nearsurface model variables, for instance, $10 \mathrm{~m}$ wind speed for SS, and soil moisture and wind for DU. In contrast, for OM, $\mathrm{BC}$ and $\mathrm{SO}_{4}$, anthropogenic sources for $\mathrm{OM}, \mathrm{BC}$ and $\mathrm{SO}_{2}$ are read from external data sets including fire-related information using the analysis of MODIS and SEVIRI satellite observations (Kaiser et al., 2012). The ECMWF IFS aerosol scheme accounts for tropospheric aerosols, whereas stratospheric aerosols are not included in the configuration, as stratospheric aerosol loadings were very small during the period under investigation. Similarly, the emission of aerosols by volcanoes is not presented in the following results. For the tropospheric aerosols, the sedimentation of the particles, dry deposition and wet deposition by large-scale and convective precipitation are included.

The size distribution of SS and DU are represented using three size bins. The SS aerosol bin limits are at 0.03, 0.5, 5 and $20 \mu \mathrm{m}$. Similarly, the DU bin limits are at $0.03,0.55,0.9$ and $20 \mu \mathrm{m}$. The above limits are chosen so that roughly 10,20 and $70 \%$ of the total mass of each aerosol type are in the various bins. The $\mathrm{OM}$ and $\mathrm{BC}$ are presented in two categories, where both the hydrophobic and hydrophilic components are taken into account. The sulfur cycle is considered via a precursor variable $\mathrm{SO}_{2}$ transformed into a sulfate aerosol $\left(\mathrm{SO}_{4}\right)$ with a timescale simply dependent on latitude (as in Huneeus and Boucher, 2007), but no gaseous chemistry parameterizations.

When computing the optical depth for the hygroscopic components ( $\mathrm{SS}, \mathrm{OM}, \mathrm{BC}, \mathrm{SO}_{4}$ ), optical properties are used that account for the relative humidity prevalent in each relevant layer.

MODIS AOD data both over land and over oceans are assimilated. However, as, for example, Zhang and Reid (2006) showed, MODIS AOD needs to be corrected before assimilation. Compared to the original aerosol analysis system (as documented in Benedetti et al., 2009 for the GEMS reanalysis Global and regional Earth-system Monitoring using 
Satellite and in situ data), the MACC aerosol analysis system differs fundamentally in the way the observations constrain the analysis through a different definition of observation errors and the introduction of a variational bias correction (Morcrette et al., 2011). The GEMS observation errors on MODIS AOD were assigned as a percentage of the AOD plus a correction depending on the scattering angle. This did not allow the analysis to correct large values of AOD due to the correspondingly large errors assigned to the observations. As a result, the GEMS reanalysis was shown to be biased with respect to the assimilated observations (Benedetti et al., 2008). Therefore, in the MACC reanalysis, the observation errors are fixed to values of 0.1 over land and 0.05 over the ocean. Additionally, a variational bias correction was implemented based on the operational setup for assimilated radiances developed by Dee and Uppala (2008). The bias model for the MODIS data consists in a global constant, which is adjusted variationally in the minimization based on the firstguess departures. As a result, the MACC analysis is not biased with respect to the MODIS observations. Furthermore, this approach has the advantage to be tied to the optimization of the cost function, and being estimated online, does not require previous pre-processing of the observations. The bias error model allows more complex treatment with the addition of other bias predictors (relevant for AOD, e.g., instrument geometry, viewing angle, cloud cover, wind speed, etc.).

\subsection{Ground-based measurements}

AERONET (AErosol RObotic NETwork) is a global network of ground-based sun photometer measurements of aerosol optical properties, such as aerosol optical depth, single scattering albedo and particle size distribution. AERONET is equipped with CIMEL sun/sky spectral radiometers, taking measurements of the direct sun radiance with $1.2^{\circ}$ full field of view at eight spectral bands $(340,380,440,500$, 670, 870, 940, $1020 \mathrm{~nm}$ ) (Holben et al., 1998). The measurements are taken automatically every 15 min during daylight hours. Standard processing includes operational cloud screening and generates AODs from these measurements. The AERONET radiometers also perform hourly sky scans in the principal and cross-almucantar plane at 440, 675, 870, $1020 \mathrm{~nm}$, from which aerosol size distributions and complex refractive indices are derived (Dubovik et al., 2000). The AOD data are available in three categories: level 1.0 (unscreened), level 1.5 (cloud screened), and level 2.0 (assured quality). For this study we use level 2.0 AOD values.

AERONET AOD data have high accuracy of $<0.01$ for wavelengths longer than $440 \mathrm{~nm}$ and $<0.02$ for shorter wavelengths (Eck et al., 1999; Holben et al., 1998). Because of its long operating history, good coverage of various regions of the globe and high data quality, AERONET data has been used in various satellite and model validation studies as the reference standard for AOD measurements.

\subsection{Comparing modeled and measured data}

AOD measurements are made at a single point at a certain moment, while the hourly model data represents a spatial and temporal mean in an approximately 0.71 degrees $(80 \mathrm{~km})$ grid box.

For the comparison we use two different data sets, consisting of total AOD and AOD of five components (SS, DU, OC, $\mathrm{BC}, \mathrm{SO}_{4}$ ). For the total AOD, we compare each hourly forecasted AOD in the MACC system at 340 and $500 \mathrm{~nm}$ with the average of the ground-based measurements within $\pm 30 \mathrm{~min}$ from the model hour. This was done to have a temporal mean value from the pointwise measurements, which is arguably better comparable with the spatial mean represented by the model fields. However, the AOD comparison of five components is available only at $550 \mathrm{~nm}$. In this case, the AERONET $\mathrm{AOD}_{500}$ values were extrapolated to $\mathrm{AOD}$ at $550 \mathrm{~nm}$ using

$\mathrm{AOD}_{\mathrm{aer}, 550}=\mathrm{AOD}_{\mathrm{aer}, 500} \cdot\left(\frac{550}{500}\right)^{-\alpha}$,

where $\alpha$ is the AERONET Angström exponent of the wavelength range $440-870 \mathrm{~nm}$. In this case, monthly instead of hourly averages were considered. For the comparison, the nearest model gridpoint to the actual validation site was used.

The following equations define the statistics, which were used for evaluating the performance of the hourly modeled versus measured AOD. The relative mean bias (rMB) was calculated as

$\mathrm{rMB}=\frac{\mathrm{MB}}{\overline{x_{\mathrm{aer}}}}=\frac{\frac{1}{n} \sum_{i=1}^{n}\left(x_{\mathrm{ec}}(i)-x_{\mathrm{aer}}(i)\right)}{\overline{x_{\mathrm{aer}}}}$,

where MB is mean bias, $\overline{x_{\mathrm{aer}}}$ mean of measured values $x_{\mathrm{aer}}$, $x_{\mathrm{ec}}(i)$ the ECMWF modeled variable, $x_{\mathrm{aer}}(i)$ the variable observed by AERONET and $n$ the number of data values. Relative root mean square difference (rRMSD) is defined as

$\mathrm{rRMSD}=\frac{\mathrm{RMSD}}{\overline{x_{\mathrm{aer}}}}=\frac{\sqrt{\frac{1}{n} \sum_{i=1}^{n}\left(x_{\mathrm{ec}}(i)-x_{\mathrm{aer}}(i)\right)^{2}}}{\overline{x_{\mathrm{aer}}}}$,

where RMSD is a root mean square difference. The correlation coefficient (CC) is also calculated.

\section{Results}

In this section we present the performance of the MACC AOD as compared to ground-based AERONET observations for the period of 2003-2006. The comparison of total AOD was done at 340 and $500 \mathrm{~nm}$ and the AOD of different components at $550 \mathrm{~nm}$. Twelve AOD sites (Fig. 1) were selected for the comparison. We chose sites where both wavelengths (340 and $500 \mathrm{~nm}$ ) are available that have data for the period 2003-2006. The selected sites were categorized in three 


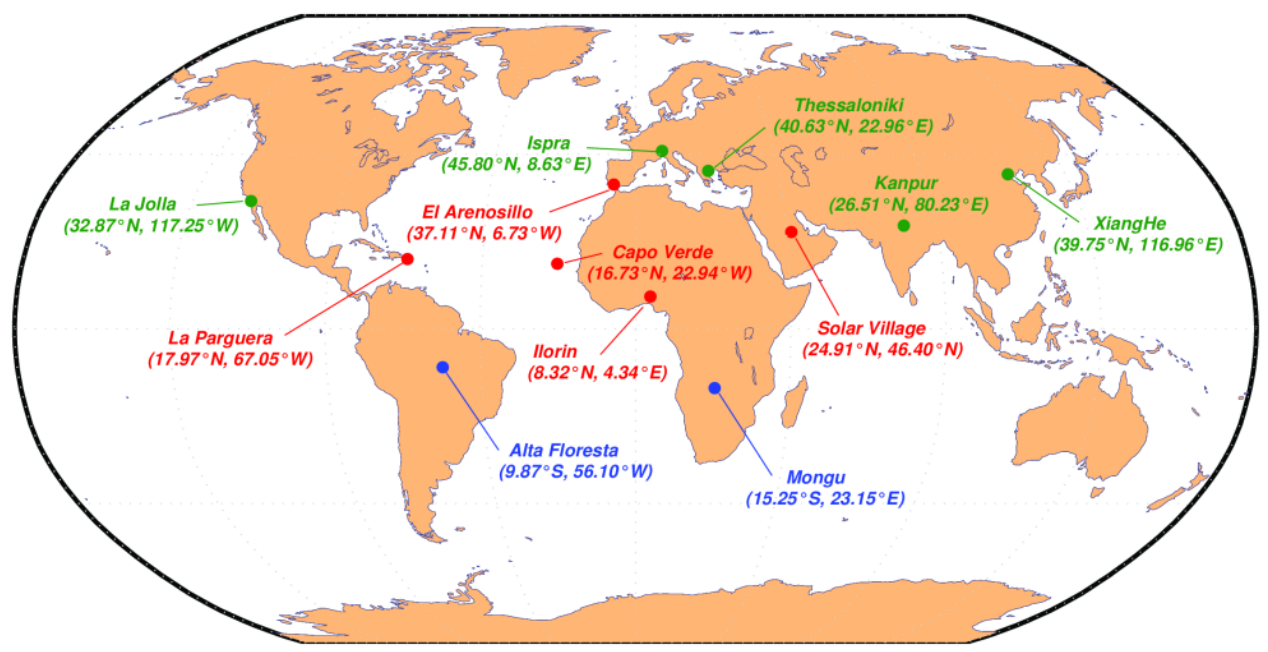

Fig. 1. Map view of AERONET stations that were included in the study. Sites are color-coded according to expected aerosol type: urban/anthropogenic (green), biomass burning (blue), and dust (red).

groups: urban/anthropogenic, biomass burning and dust. This was done in order to examine the model-measurements performance for different aerosol types. It should be noted, however, that although these groups indicate the aerosol type dominating the site, other aerosol types might also be contributing.

In the following, we discuss results site by site. Statistics as defined in Sect. 2.3 are given in Table 1 for each site at 340 and $500 \mathrm{~nm}$.

\subsection{Urban/anthropogenic}

Urban aerosols are composed of a variety of aerosol types and components, including water-soluble inorganic species (e.g., sulfate, nitrate, ammonium), condensed organic species, elemental or black carbon, and mineral dust. The main sources of anthropogenic aerosols are traffic, smallscale wood combustion, power plants, industries, ships. Urban aerosols are significant contributors to the global aerosol burden.

Ispra is an urban/industrial area in northern Italy. Figure $2 \mathrm{a}$ shows a comparison between the MACC $\mathrm{AOD}_{550}$ and AERONET AOD 550 , extrapolated to $550 \mathrm{~nm}$ as explained above (Eq. 1). The figure also shows the contribution by different aerosol components according to the MACC data. Both the model and AERONET show a seasonality with higher $\mathrm{AOD}_{550}$ values in the spring and summer. Springsummer maximum is attributed to the contributions of various processes, such as stagnant synoptic meteorological patterns, secondary aerosol photochemical formation, hygroscopic growth of hydrophilic urban aerosols, and smoke from seasonal biomass burning (Kambezidis and Kaskaoutis, 2008). The model captures the general $\mathrm{AOD}_{550}$ variation fairly well, although occasional peak values, for example,
March 2003 and October 2004, are clearly underestimated. The ECMWF model indicates, that $\mathrm{SO}_{4}$ is the main aerosol component in Ispra, in agreement with other studies suggesting, that the aerosol load is dominated by anthropogenic particles (e.g., Gobbi et al., 2007; Kambezidis and Kaskaoutis, 2008). The model furthermore shows a clear contribution by DU in the summer months.

Figure $2 \mathrm{~b}$ presents the performance of the MACC $\mathrm{AOD}_{340,500}$ versus AERONET $\mathrm{AOD}_{340,500 \text {. The figure }}$ shows a large scatter and clear underestimation, which is stronger at $340 \mathrm{~nm}$ than at $500 \mathrm{~nm}\left(\mathrm{MB}_{340}=-0.21\right.$, $\left.\mathrm{MB}_{500}=-0.09\right)$. There is a reasonable correlation that is similar at both wavelengths $\left(\mathrm{CC}_{340}=0.61, \mathrm{CC}_{500}=0.60\right.$; all statistics are given in Table 1). A major part of the $\mathrm{AOD}_{340,500}$ values are below 2.5, with few exceptionally large values that go up to 4 (Fig. 2b). However, these large values do not have a significant influence on the correlation and the linear fit. In order to test whether these high values influence the correlation and the linear fit, we removed $\mathrm{AOD}_{340,500}>2.5$ (5 values) when computing statistics. The $\mathrm{CC}_{340}$ increased from 0.61 to 0.64 , while the other statistics stayed essentially the same.

Figure $2 \mathrm{c}$ shows the ratio and absolute difference between modeled and measured AOD at $340 \mathrm{~nm}$ in Ispra over the course of the year. Both, the ratio and the difference, show underestimation of $\mathrm{AOD}_{340}$ for all months. Although the absolute difference (blue line) stays rather constant throughout the year, the ratio (green line) is higher in the summer months.

Kanpur is an urban site, located in the central part of the Indo-Gangetic Basin (IGB) and it is usually affected by high pollution. The IGB experiences four seasons annually (Dey and Tripathi, 2008): winter (December-February), premonsoon (March-May), monsoon (June-September), and 

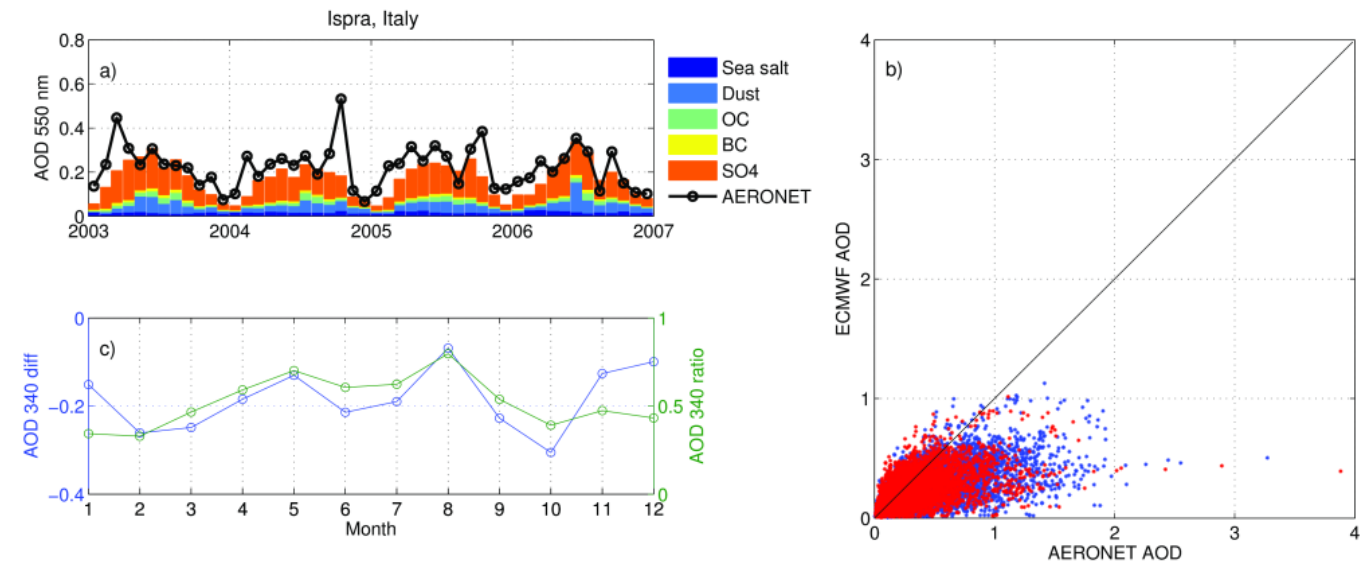

Fig. 2. ECMWF AOD compared to AERONET AOD in Ispra. (a) Monthly mean AOD $_{550}$ for the period 2003-2006. The modeled total $\mathrm{AOD}_{550}$ consists of five components: sea salt, (SS) dust (DU), organic carbon (OC), black carbon (BC), and sulfate ( $\left.\mathrm{SO}_{4}\right)$. The corresponding monthly mean $\mathrm{AOD}_{550}$ from AERONET is shown with a black line (extrapolated using Ångström exponent at wavelength range of 440-870 nm). (b) Modeled AOD with respect to measured AOD at $340 \mathrm{~nm}$ (blue dots) and $500 \mathrm{~nm}$ (red dots). Data points include only observations, when $\mathrm{AOD}$ of both wavelengths are available. Black line represents $1: 1$ line. (c) Ratio $\left(\mathrm{AOD}_{\mathrm{ec}} / \mathrm{AOD}_{\mathrm{aer}}\right.$, green line) and absolute difference $\left(\mathrm{AOD}_{\mathrm{ec}}-\mathrm{AOD}_{\mathrm{aer}}\right.$, blue line) between modeled and measured $\mathrm{AOD}$ at $340 \mathrm{~nm}$.
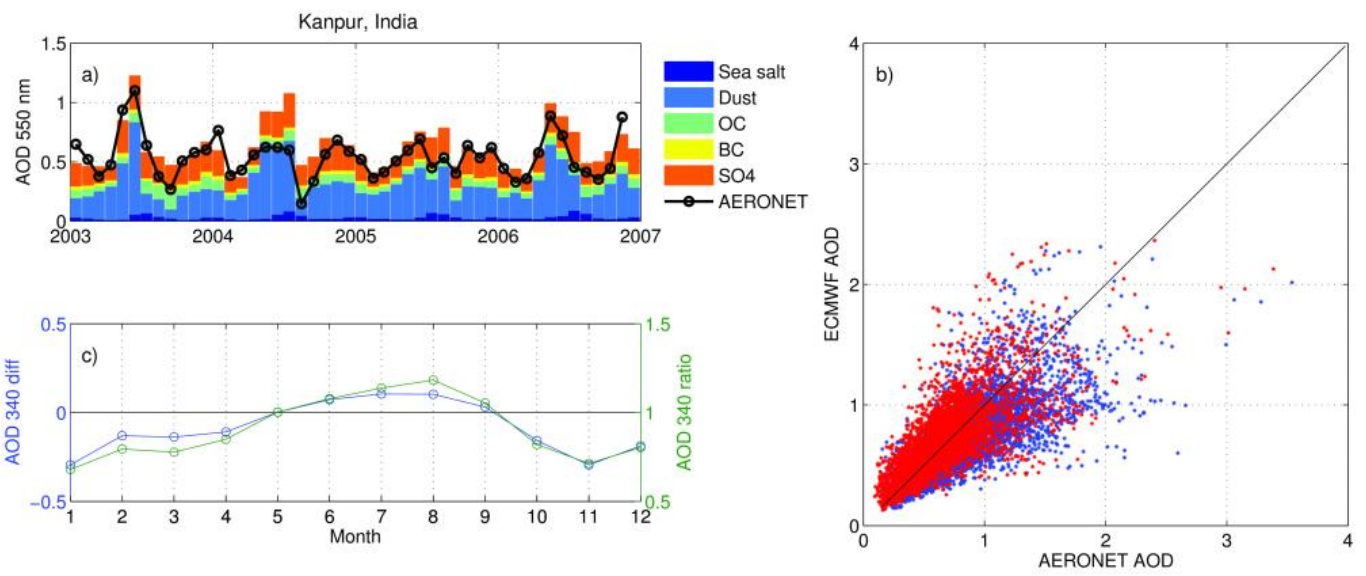

Fig. 3. Same as Fig. 2, but for Kanpur.

post-monsoon (October-November). High AOD $_{550}$ values, prevailing throughout the year, can also be seen from both the model and the measurements in Fig. 3a, where the monthly mean $\mathrm{AOD}_{550}$ goes up to 1 . Generally, the ECMWF model tends to follow the measurements rather well. For example, both the AERONET and the model show the highest monthly values in May-June of 2003 and 2006. During this time, the model shows an increase in dust aerosols, in particular. On the other hand, the model clearly overestimates the MayAugust $\mathrm{AOD}_{550}$ of 2004.

Figure $3 \mathrm{~b}$ shows large scatter between the MACC $\mathrm{AOD}_{340,500}$ and AERONET $\mathrm{AOD}_{340,500}$ in Kanpur, especially for higher $\mathrm{AOD}_{340,500}$ values. The correlation is fairly good $\left(\mathrm{CC}_{340}=0.72, \mathrm{CC}_{500}=0.75\right)$, and the underestimation is smaller than for Ispra $\left(\mathrm{MB}_{340}=-0.13, \mathrm{MB}_{500}=\right.$
0.03). The difference in the performance between $\mathrm{AOD}_{340}$ and $\mathrm{AOD}_{500}$ is similar to that observed in Ispra, with stronger underestimation at $\mathrm{AOD}_{340}$. Over the course of the year, the $\mathrm{AOD}_{340}$ shows an underestimation during winter (both ratio and difference) and slight overestimation in June-August (Fig. 3c). Thus, the overestimation seems to be related to the monsoon, when aerosols are washed out from the atmosphere. This may have to do with the representation of rain and aerosol removal processes in the ECMWF model.

La Jolla is a site on the shore of the Pacific Ocean in southern California within the northern city limits of San Diego. The site is observed to be rather clean throughout the year with most of the monthly mean AOD $_{550}$ values lying below 0.2 (Fig. 4a, black line). The ECMWF model is in rather good agreement with the measurements, typically showing 
Table 1. Statistics describing how well the modeled AOD match corresponding measured values at 340 and $500 \mathrm{~nm}$. $\overline{\mathrm{AOD}_{\mathrm{ec}}}$ and $\overline{\mathrm{AOD}} \overline{\mathrm{aer}}$ is a mean of modeled and measured AOD values, respectively. MB stands for mean bias, rMB for relative mean bias, RMSD for root mean square difference, rRMSD for relative root mean square difference, and CC for correlation coefficient. $N$ is the number of data values used to calculate the statistics.

\begin{tabular}{|c|c|c|c|c|c|c|c|c|}
\hline Site $/ \lambda$ & $\overline{\mathrm{AOD}_{\mathrm{ec}}}$ & $\overline{\mathrm{AOD}_{\mathrm{aer}}}$ & MB & rMB & RMSD & rRMSD & $\mathrm{CC}$ & $N$ \\
\hline \multicolumn{9}{|c|}{ Urban/anthropogenic } \\
\hline \multicolumn{9}{|l|}{ Ispra } \\
\hline $340 \mathrm{~nm}$ & 0.23 & 0.44 & -0.21 & -0.47 & 0.34 & 0.78 & 0.64 & 6493 \\
\hline $500 \mathrm{~nm}$ & 0.20 & 0.29 & -0.09 & -0.30 & 0.23 & 0.78 & 0.60 & 6493 \\
\hline \multicolumn{9}{|l|}{ Kanpur } \\
\hline $340 \mathrm{~nm}$ & 0.72 & 0.85 & -0.13 & -0.15 & 0.29 & 0.34 & 0.72 & 5005 \\
\hline $500 \mathrm{~nm}$ & 0.67 & 0.63 & 0.03 & 0.05 & 0.22 & 0.35 & 0.75 & 5005 \\
\hline \multicolumn{9}{|l|}{ La Jolla } \\
\hline $340 \mathrm{~nm}$ & 0.17 & 0.18 & -0.01 & -0.05 & 0.10 & 0.56 & 0.49 & 3346 \\
\hline $500 \mathrm{~nm}$ & 0.15 & 0.11 & 0.03 & 0.29 & 0.08 & 0.71 & 0.49 & 3346 \\
\hline \multicolumn{9}{|c|}{ Thessaloniki } \\
\hline $340 \mathrm{~nm}$ & 0.29 & 0.47 & -0.18 & -0.38 & 0.25 & 0.53 & 0.72 & 2568 \\
\hline $500 \mathrm{~nm}$ & 0.26 & 0.29 & -0.03 & -0.10 & 0.13 & 0.46 & 0.68 & 2568 \\
\hline \multicolumn{9}{|l|}{ Xianghe } \\
\hline $340 \mathrm{~nm}$ & 0.51 & 0.88 & -0.37 & -0.42 & 0.65 & 0.73 & 0.83 & 4237 \\
\hline $500 \mathrm{~nm}$ & 0.46 & 0.65 & -0.19 & -0.30 & 0.47 & 0.72 & 0.80 & 4237 \\
\hline \multicolumn{9}{|c|}{ Biomass burning } \\
\hline \multicolumn{9}{|c|}{ Alta Floresta } \\
\hline $340 \mathrm{~nm}$ & 0.45 & 0.63 & -0.18 & -0.28 & 0.44 & 0.69 & 0.89 & 4150 \\
\hline $500 \mathrm{~nm}$ & 0.32 & 0.39 & -0.07 & -0.17 & 0.27 & 0.70 & 0.87 & 4150 \\
\hline \multicolumn{9}{|l|}{ Mongu } \\
\hline $340 \mathrm{~nm}$ & 0.35 & 0.54 & -0.14 & -0.30 & 0.24 & 0.51 & 0.90 & 6387 \\
\hline $500 \mathrm{~nm}$ & 0.24 & 0.30 & -0.03 & -0.13 & 0.12 & 0.44 & 0.89 & 6387 \\
\hline \multicolumn{9}{|c|}{ Dust } \\
\hline \multicolumn{9}{|c|}{ Capo Verde } \\
\hline $340 \mathrm{~nm}$ & 0.38 & 0.42 & -0.04 & -0.10 & 0.16 & 0.38 & 0.87 & 1365 \\
\hline $500 \mathrm{~nm}$ & 0.38 & 0.35 & 0.03 & 0.07 & 0.15 & 0.43 & 0.87 & 1365 \\
\hline \multicolumn{9}{|c|}{ El Arenosillo } \\
\hline $340 \mathrm{~nm}$ & 0.21 & 0.21 & 0.00 & 0.01 & 0.08 & 0.40 & 0.82 & 1177 \\
\hline $500 \mathrm{~nm}$ & 0.19 & 0.14 & 0.05 & 0.33 & 0.08 & 0.57 & 0.86 & 1177 \\
\hline \multicolumn{9}{|l|}{ Ilorin } \\
\hline $340 \mathrm{~nm}$ & 0.59 & 0.93 & -0.33 & -0.36 & 0.50 & 0.54 & 0.69 & 4317 \\
\hline $500 \mathrm{~nm}$ & 0.55 & 0.75 & -0.20 & -0.26 & 0.38 & 0.51 & 0.71 & 4317 \\
\hline \multicolumn{9}{|c|}{ La Parguera } \\
\hline $340 \mathrm{~nm}$ & 0.20 & 0.19 & 0.00 & 0.02 & 0.09 & 0.45 & 0.68 & 4327 \\
\hline $500 \mathrm{~nm}$ & 0.19 & 0.14 & 0.05 & 0.33 & 0.08 & 0.56 & 0.80 & 4327 \\
\hline \multicolumn{9}{|c|}{ Solar Village } \\
\hline $340 \mathrm{~nm}$ & 0.46 & 0.40 & 0.05 & 0.14 & 0.19 & 0.46 & 0.68 & 10405 \\
\hline $500 \mathrm{~nm}$ & 0.45 & 0.33 & 0.12 & 0.38 & 0.22 & 0.66 & 0.66 & 10405 \\
\hline
\end{tabular}

a slightly larger $\mathrm{AOD}_{550}$ than AERONET. Both AERONET and the model show a seasonal cycle with somewhat higher $\mathrm{AOD}_{550}$ in the summer months. The figure also shows, that the model exhibits two major aerosol types for La Jolla: DU that is transported mainly from Mojave and Colorado deserts (Muhs et al., 2007) and $\mathrm{SO}_{4}$ most likely from the metropolitan areas of western part of US.
The La Jolla site shows large scatter (Fig. 4b) and rather low correlation $\left(\mathrm{CC}_{340}=\mathrm{CC}_{500}=0.49\right)$. This is lower than for Ispra and Kanpur, and may to some extent be explained by the small range in $\mathrm{AOD}_{340,500}$ (most of the $\mathrm{AOD}_{340,500}$ values are below 0.5). In this case, the outliers do not effect the correlation, but do have a significant influence on the linear fit. The original linear fits were $\mathrm{AOD}_{\mathrm{ec}, 340}=0.34 \cdot \mathrm{AOD}_{\mathrm{aer}, 340}+0.11$, 

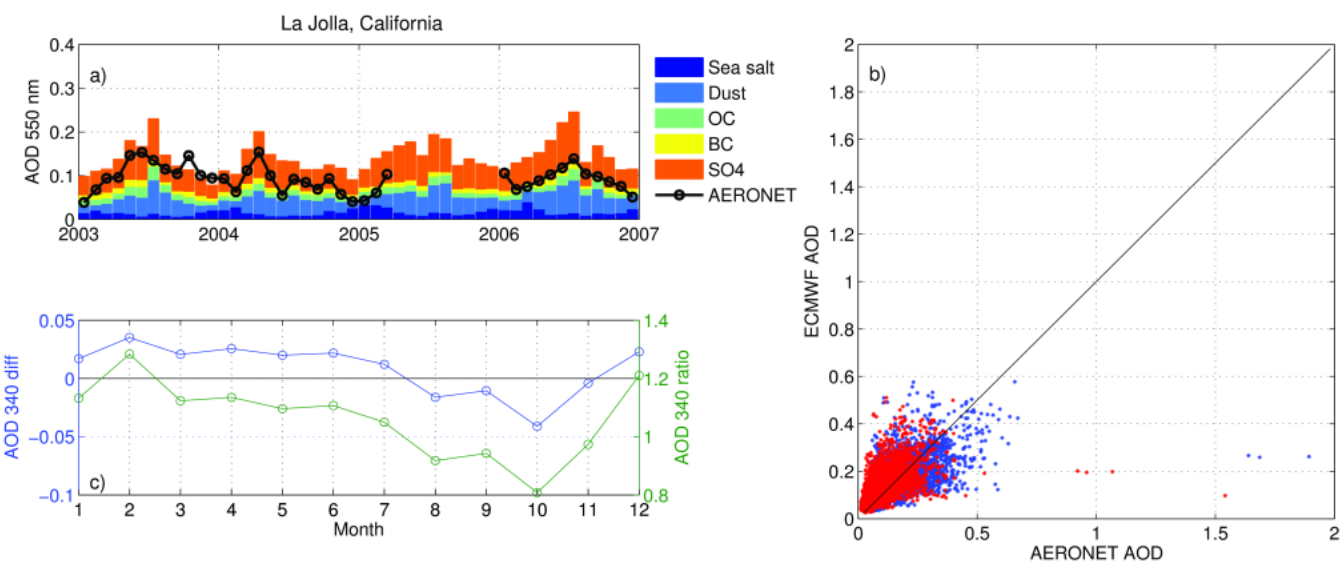

Fig. 4. Same as Fig. 2, but for La Jolla.

$\mathrm{AOD}_{\mathrm{ec}, 500}=0.44 \cdot \mathrm{AOD}_{\mathrm{aer}, 340}+0.10$. When we removed $\mathrm{AOD}_{340,500}>0.8$ values ( 8 values), the linear fits were as follows: $\mathrm{AOD}_{\mathrm{ec}, 340}=0.47 \cdot \mathrm{AOD}_{\mathrm{aer}, 340}+0.09, \mathrm{AOD}_{\mathrm{ec}, 500}=$ $0.56 \cdot \mathrm{AOD}_{\mathrm{aer}, 340}+0.08$. In contrast to Ispra and Kanpur, $\mathrm{La}$ Jolla exhibits a small positive mean bias at $500 \mathrm{~nm}$ and small negative bias at $340 \mathrm{~nm}\left(\mathrm{MB}_{500}=0.03, \mathrm{MB}_{340}=-0.01\right)$, and only a small difference between the performance of $\mathrm{AOD}_{340}$ and $\mathrm{AOD}_{500}$. Figure $4 \mathrm{c}$ shows a small ratio and difference with a slight underestimation in August-November and an overestimation for the rest of the months.

AERONET station in Thessaloniki is located at the center of the city. The site is mainly surrounded by pine-covered hills to the north, concrete buildings from east and west, and the sea to the south. The ECMWF shows rather high monthly mean $\mathrm{AOD}_{550}$ values that go up to 0.4 (Fig. 5a), and agrees with Kazadzis et al. (2007) stating, that the site is characterized by heavy aerosol load and increased air pollution. The model shows that high $\mathrm{AOD}_{550}$ are attributed to an increase in $\mathrm{SO}_{4}$ and partly in DU load. Thessaloniki AERONET data are available for only sixteen months. However, the modeled $\mathrm{AOD}_{550}$ values agree fairly well with AERONET during this period, with clearly higher values in the summer than in winter. For November 2005, and April and October 2006, there is, however, a more pronounced difference between the model and the measurements.

Similar to the previous stations, Thessaloniki also shows a rather large scatter between the MACC and AERONET $\mathrm{AOD}_{340,500}$ (Fig. 5b). The $\mathrm{AOD}_{340}$ spans a larger range than $\mathrm{AOD}_{500}$. In order to examine this feature, we compared the Angström exponent from AERONET and the model, calculated using 340 and $500 \mathrm{~nm}$. The Angström exponent from the ECMWF model was too low for Thessaloniki (not shown), where anthropogenic (fine mode) aerosols dominate. To understand this behavior, we compared coarse $(\mathrm{SS}+\mathrm{DU})$ and fine $\left(\mathrm{OC}+\mathrm{BC}+\mathrm{SO}_{4}\right)$ mode $\mathrm{AOD}$ at $550 \mathrm{~nm}$ from the ECMWF with coarse and fine mode AOD $_{550}$ from AERONET Spectral Deconvolution Algorithm
(SDA) retrievals. The AERONET $\mathrm{AOD}_{550}$ was extrapolated from $\mathrm{AOD}_{500} \mathrm{~nm}$ (Eq. 1). The correlation is higher for coarse mode $\left(\mathrm{CC}_{\mathrm{C}}=0.75\right)$ than for fine $\left(\mathrm{CC}_{\mathrm{F}}=0.64\right)$ mode $\mathrm{AOD}_{550}$. The underestimation of fine mode $\left(\mathrm{rMB}_{\mathrm{F}}=-0.20\right)$ and overestimation of coarse mode $\left(\mathrm{rMB}_{\mathrm{C}}=0.47\right)$ indicates, that there are most likely too much dust and too little fine particles in the MACC system. This combination contributes to the effective size being shifted towards larger particles.

Furthermore, the correlation is rather good for both wavelengths $\left(\mathrm{CC}_{340}=0.72, \mathrm{CC}_{500}=0.68\right)$. There is a significant negative mean bias at $340 \mathrm{~nm}\left(\mathrm{MB}_{340}=-0.18\right)$, while the bias at $500 \mathrm{~nm}$ is small $\left(\mathrm{MB}_{500}=-0.03\right)$. The underestimation at $340 \mathrm{~nm}$ can be seen almost all year round (Fig. 5c). We emphasize that, due to the short period of available AERONET data, the seasonal behavior is not representative for the whole period of 2003-2006.

Xianghe is a rural site, located about $80 \mathrm{~km}$ southeast of central Beijing. The region is often covered by a thick layer of haze due primarily to anthropogenic emissions (Li et al., 2007). Xianghe, as well as Kanpur, is a very polluted place. This is also seen from Fig. 6a, where both modeled and measured monthly mean $\mathrm{AOD}_{550}$ values go up to around 1. The ECMWF model shows a seasonal cycle with maximum in summer and minimum in winter. Furthermore, the model shows that DU and $\mathrm{SO}_{4}$ are the major components, in particular in the summer. The summer of 2003 is exceptional with a large contribution by OC, which is linked to biomass burning. Unfortunately, no AERONET data are available to support this behavior. However, the absence of burning activities seen in the MACC AOD 550 data for 2004-2006 is slightly contradicting to the recent study of Xue et al. (2012), where the annual agricultural biomass burning season from May to August is identified as common in this region. More than $2 \mathrm{yr}$ of AERONET $\mathrm{AOD}_{550}$ data show rather good agreement with the MACC AOD $_{550}$, although the model tends to slightly overestimate the summer months. 

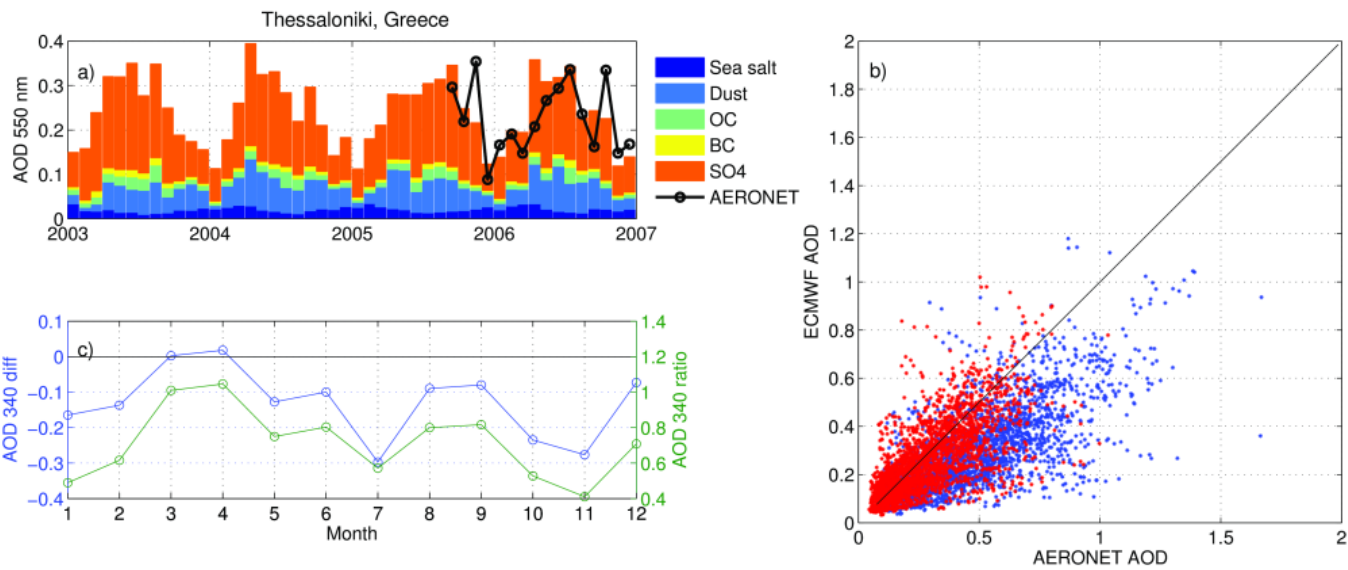

Fig. 5. Same as Fig. 2, but for Thessaloniki.
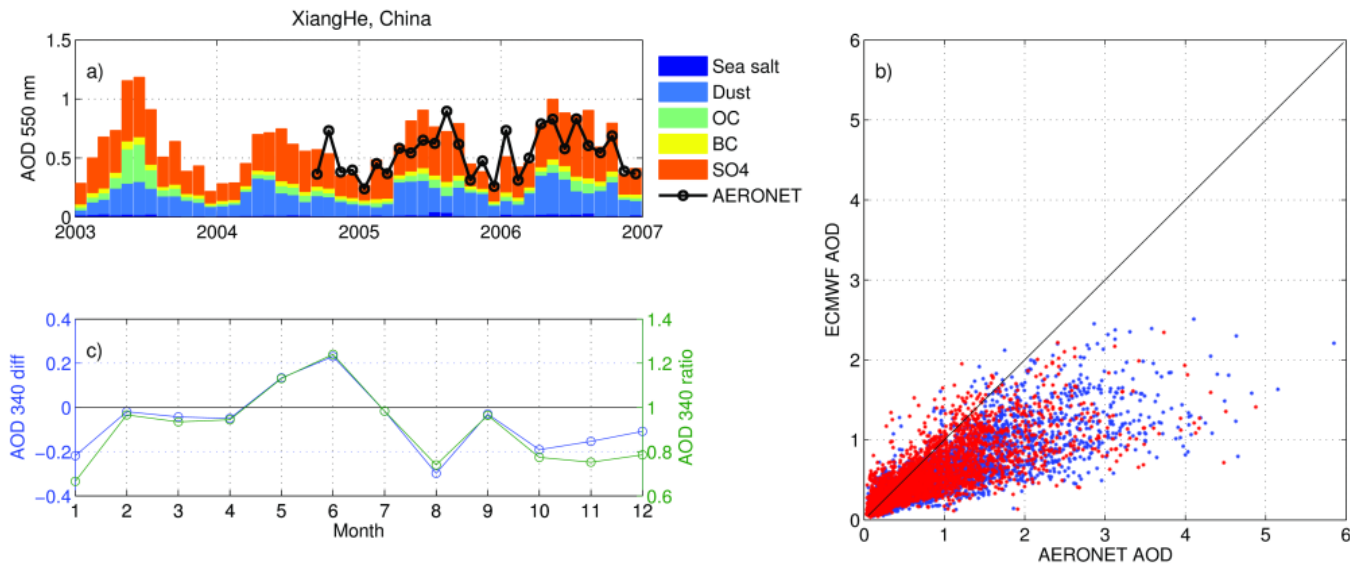

Fig. 6. Same as Fig. 2, but for Xianghe.

Figure $6 \mathrm{~b}$ shows the largest span of $\mathrm{AOD}_{340,500}$ values of all sites included in this study. The maximum $\mathrm{AOD}_{340}$ at Xianghe reaches almost 6 . The site exhibits smaller scatter than for Thessaloniki and good correlation $\left(\mathrm{CC}_{340}=0.83\right.$, $\left.\mathrm{CC}_{500}=0.80\right)$. However, the modeled $\mathrm{AOD}_{340,500}$ values are smaller, compared to measured, by a factor of 2-3. Among all the urban sites, Xianghe exhibits the largest underestimation, which is almost two times larger for $340 \mathrm{~nm}\left(\mathrm{MB}_{340}=\right.$ $-0.37)$ than for $500 \mathrm{~nm}\left(\mathrm{MB}_{500}=-0.19\right)$. In spite of the overall underestimation, Fig. 6c shows that the ECMWF model tends to overestimate $\mathrm{AOD}_{340}$ values in May-June.

\subsection{Biomass burning}

Biomass burning is a major source of atmospheric trace gases and particles (Andreae and Crutzen, 1997). Savannah fires, domestic and industrial biofuel use, forest fires, and crop residue burning are thought to account for most of the global biomass burning (in the given order) (Akagi et al., 2011). The contribution of these smoke particles to the global aerosol burden is especially important because they are the major anthropogenic aerosol source in the Southern Hemisphere (Koren et al., 2007).

Alta Floresta is located near an airfield in Alta Floresta, in the northern part of the state Mato Grosso, lying on the western extension of the Brazilian Plateau. The site is directly influenced by biomass burning, which associates with either deforestation or with agricultural practices and occurs during the latter half of the dry season (August-September). This biomass burning produces a large amount of smoke with high AOD, especially during the peak burning season months (Eck et al., 1999). Large contribution of biomass burning aerosols $(\mathrm{OC}+\mathrm{BC})$, in particular in late summerautumn months, is also seen in Fig. 7a. The MACC AOD 550 data shows that during the burning season monthly mean $\mathrm{AOD}_{550}$ increase steadily up to $0.6-0.8$, whereas during nonburning months $\mathrm{AOD}_{550}$ values drop to below 0.2 . The overall model-measurements agreement is good throughout the years, however, the biomass burning seasons of 2005-2006 

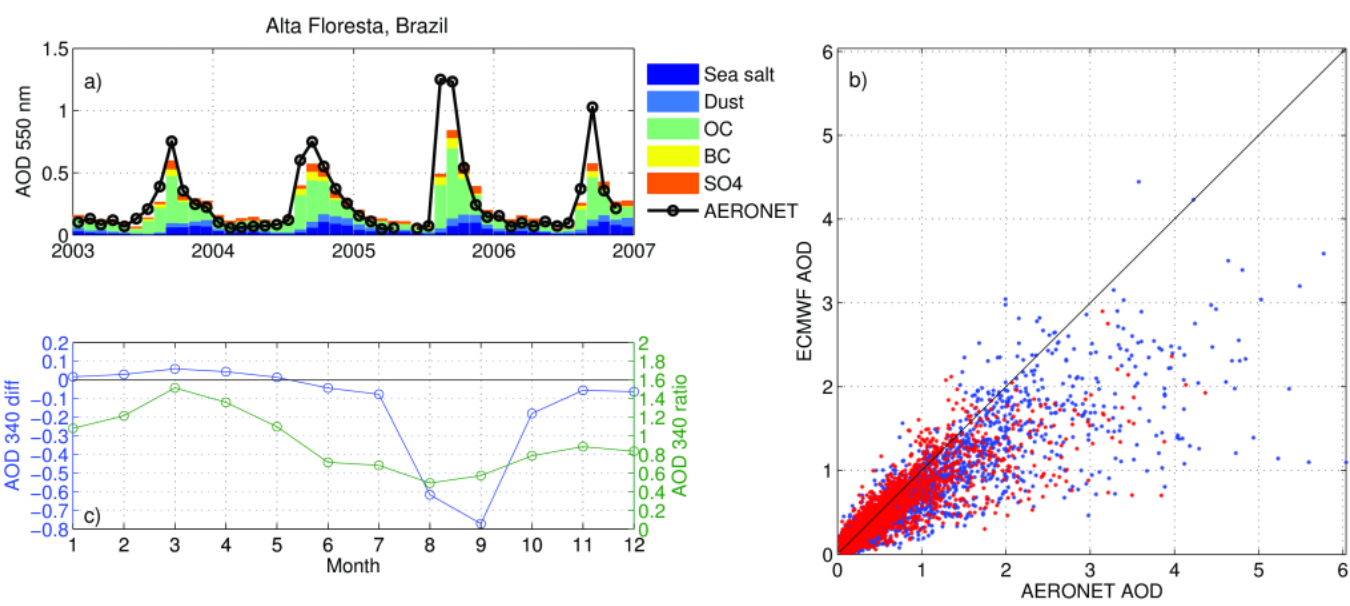

Fig. 7. Same as Fig. 2, but for Alta Floresta.
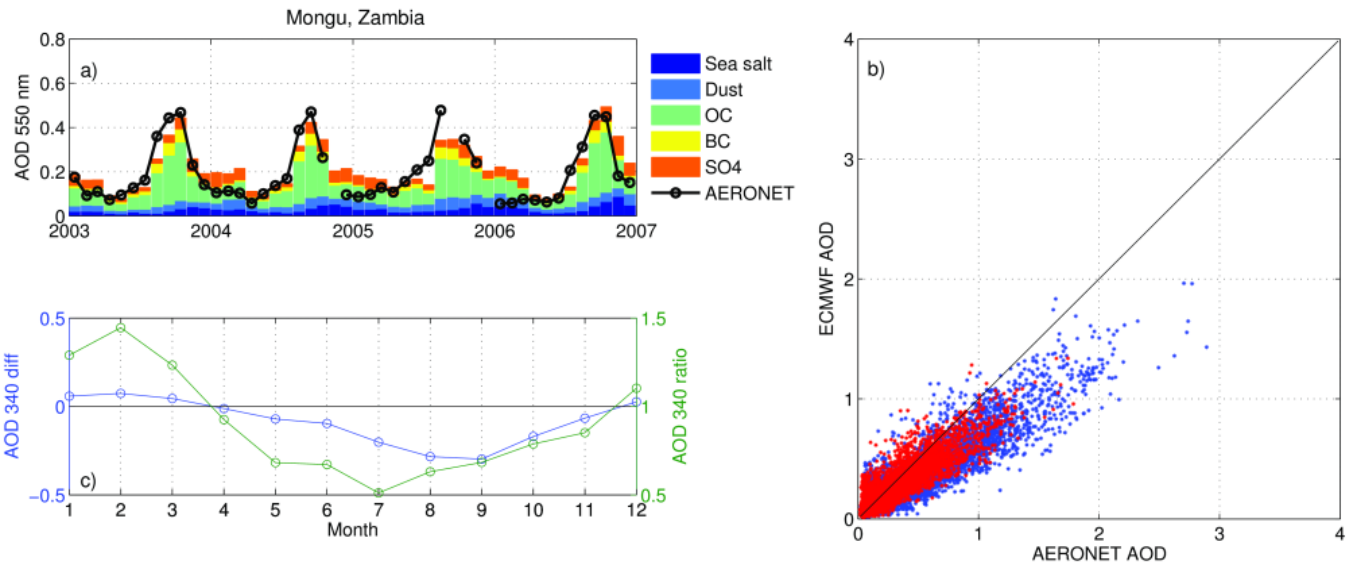

Fig. 8. Same as Fig. 2, but for Mongu.

are rather strongly underestimated. The strong underestimation in 2005 can be linked to a severe drought in western part of Amazon (Bevan et al., 2009; Marengo et al., 2008; Zeng et al., 2008), which most likely enhances the intensity of burning, thus releasing a large amount of biomass burning particles into the atmosphere.

Figure $8 \mathrm{~b}$ shows that the $\mathrm{AOD}_{340,500}$ in Alta Floresta, as well as in Xianghe, is high and reaches 6 . The site exhibits a good correlation between the modeled and measured $\mathrm{AOD}_{340,500}\left(\mathrm{CC}_{340}=0.89, \mathrm{CC}_{500}=0.87\right)$ with large scatter (Fig. 7b). The underestimation is stronger at $340 \mathrm{~nm}$ $\left(\mathrm{MB}_{340}=-0.18\right)$ than at $500 \mathrm{~nm}\left(\mathrm{MB}_{500}=-0.07\right)$. The $\mathrm{AOD}_{340}$ remains low for non-burning season (Fig. 7a), exhibiting also very low deviation in the absolute difference (Fig. 7c, blue line). The ratio (green line) shows a fairly consistent underestimation during the burning season, which translates into a large difference of -0.75 on the absolute scale.
Mongu is a site, located in a savannah region, which is a mix of open woodland and grassland. The ECMWF model shows the annual $\mathrm{AOD}_{550}$ variation being dominated by biomass burning particles, which occurs primarily during the second half of the dry season and includes the beginning of the wet season (August-November) (Fig. 8a). Compared to Alta Floresta, the burning season in Mongu is longer, and during this time the monthly mean $\mathrm{AOD}_{550}$ values are almost twice smaller. This is also seen from the AERONET measurements, where the $\mathrm{AOD}_{340}$ in Mongu goes up to 3, whereas in Alta Floresta it goes up to 6 (Fig. 8b and b). On the other hand, the $\mathrm{AOD}_{550}$ level of the non-burning season stays similarly low in both sites. The overall modelmeasurement agreement in Fig. 8a is good, however, during non-burning months, monthly mean $\mathrm{AOD}_{550}$ is overestimated by approximately 0.1 .

The performance of the MACC $\mathrm{AOD}_{340,500}$ vs. AERONET $\mathrm{AOD}_{340,500}$ for Mongu is similar to that, seen for Alta Floresta (Fig. 8b), with a slightly higher 


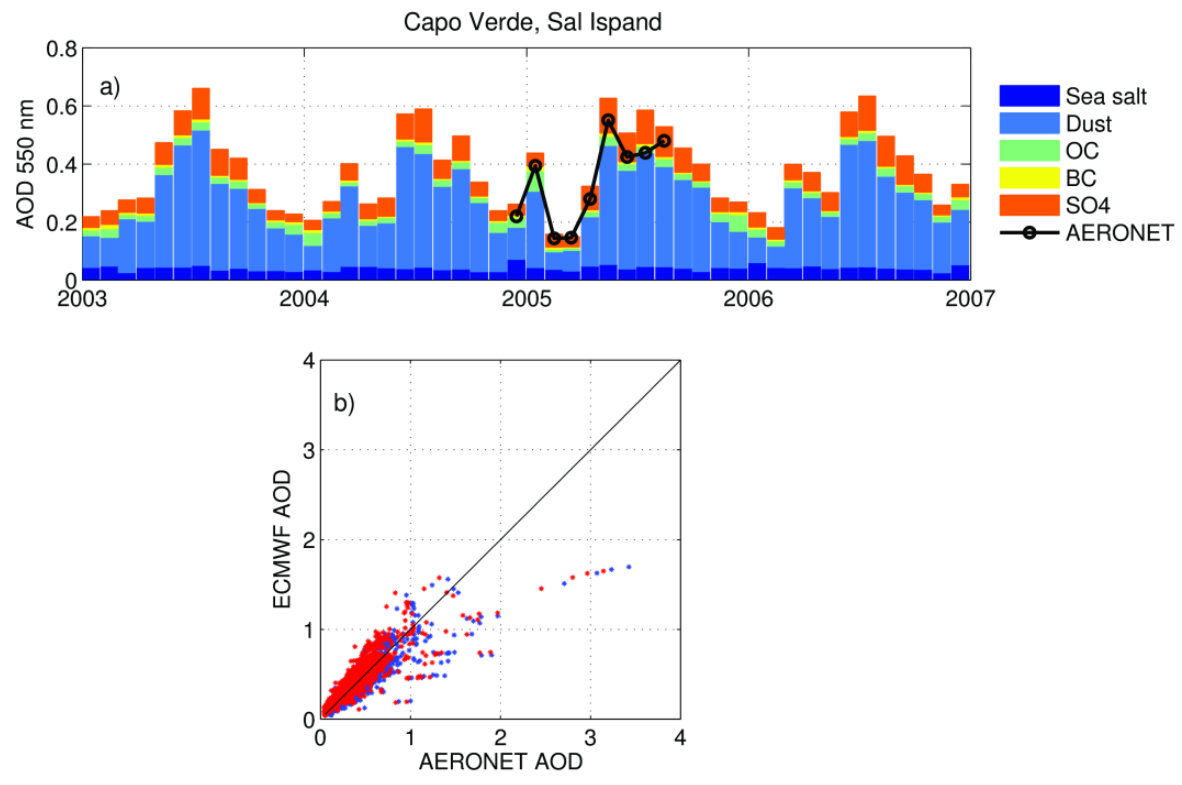

Fig. 9. Same as Fig. 2, but for Capo Verde.

correlation for Mongu $\left(\mathrm{CC}_{340}=0.90, \mathrm{CC}_{500}=0.89\right)$. Overall, Mongu exhibits the highest correlation of all sites included in our study. Mongu, as well as Alta Floresta, exhibits a negative bias, which is larger at $340 \mathrm{~nm}$ than at $500 \mathrm{~nm}\left(\mathrm{MB}_{340}=-0.14, \mathrm{MB}_{500}=-0.03\right)$. The underestimation at both wavelengths is somewhat larger for Alta Floresta than for Mongu. The yearly AOD $_{550}$ cycle is similar for both sites (Fig. 7a and Fig. 8a), also with a similar behavior in the ratio between the ECMWF and AERONET AOD 340 (Fig. 7c and Fig. 8c). However, the absolute difference (blue line) in $\mathrm{AOD}_{340}$ during the biomass burning season in Mongu is roughly half of that in Alta Floresta.

\subsection{Dust}

In a strong contrast to biomass burning and urban aerosols, which are dominated by fine mode accumulation particles, desert dust is dominated by coarse mode particles, composed of airborne soil material. Sahara is a major source of mineral dust, that subsequently spreads across the Caribbean and Mediterranean seas (where the origin of rain dust is) into northern South America, Central and North America, and Europe. Additionally, it plays a significant role in the nutrient inflow to the Amazon rainforest (Koren et al., 2006).

The AERONET site in Capo Verde is located in the Atlantic ocean, approximately $730 \mathrm{~km}$ west of Senegal, on the main path of the Saharan dust transport (Chiapello et al., 1999). High dust load throughout the years is also seen in the MACC system (Fig. 9a). Dust is more abundant in summer months, and the $\mathrm{AOD}_{550}$ shows a clear seasonal cycle with the monthly mean $\mathrm{AOD}_{550}$ typically increasing from 0.2 in the winter to around 0.5 in the summer. Only nine months of AERONET measurements were available for Capo Verde. However, the ECMWF shows a good agreement with the measurements over this period. Two $\mathrm{AOD}_{340}$ peaks are seen in the figure, one in winter and the other one in late springsummer, and both of these peaks are well presented also by the ECMWF model.

Capo Verde shows a rather small scatter (Fig. 9b) and good correlation $\left(\mathrm{CC}_{340}=\mathrm{CC}_{500}=0.87\right)$ between the MACC derived $\mathrm{AOD}_{340,500}$ values and ground-based AERONET data. Almost equal AOD values at both $340 \mathrm{~nm}$ and $500 \mathrm{~nm}$ indicate large particles such as, dust and sea salt. The systematic difference is small at both $500 \mathrm{~nm}\left(\mathrm{MB}_{500}=0.03\right)$ and $340 \mathrm{~nm}\left(\mathrm{MB}_{340}=-0.04\right)$, indicating that the model captures this dust area rather well. The Capo Verde site covers only 9 months of data, from December 2004 to August 2005, so the performance over the course of the year is not shown here.

El Arenosillo, located on the coast of the southwestern Iberian Peninsula, is often under the influence of Saharan dust transport (Toledano et al., 2007a, b). The ECMWF model shows, that the main aerosol types present at El Arenosillo site are sea salt, $\mathrm{SO}_{4}$ and desert dust (Fig. 10a). The model shows highest occurrence of dust in late winter (February, March) and summer months, which agrees well with Toledano et al. (2007b). Figure 10b shows that the highest $\mathrm{AOD}_{340,500}$ values are close to 1 . However, the monthly mean $\mathrm{AOD}_{550}$ stays below $0.2-0.3$ in summer and is approximately 0.1 in winter (Fig. 10a). The MACC AOD 550 values are larger than AERONET observations. Note, however, that El Arenosillo has the smallest number of paired data points, covering only the period from July to December 
2006. Therefore, not much can be said about the general performance of the model for this station.

At El Arenosillo, the model shows a good correlation with measured $\mathrm{AOD}_{340,500}$ values $\left(\mathrm{CC}_{340}=0.82, \mathrm{CC}_{500}=\right.$ 0.86) (Fig. 10b). There is a somewhat larger positive bias at $500 \mathrm{~nm}\left(\mathrm{MB}_{500}=0.05\right)$, whereas almost no bias at $340 \mathrm{~nm}$ $\left(\mathrm{MB}_{340}=0.00\right)$. Generally, the model tends to slightly overestimate small $\mathrm{AOD}_{340,500}$ values.

Ilorin is located in sub-Saharan Africa at the upper tip of the Guinea Savannah zone, which is under the influence of the annual alternating southward and northward passages of the intertropical convergence zone (ITCZ). The Ilorin site is highly polluted, especially, when dust is transported into the area. Measured $\mathrm{AOD}_{340}$ values go up to almost 4.5 (Fig. 11b). The ECMWF model exhibits largest contribution by dust to the $\mathrm{AOD}_{550}$ in February-March (Fig. 11a). During these months, the measured mean monthly $\mathrm{AOD}_{550}$ is around 1. The modeled $\mathrm{AOD}_{550}$ values are lower than the measured, especially, for months with higher aerosol load. Strongest dust plumes originate from the Bodélé Depression in the Chad Basin (Todd et al., 2007; Prospero et al., 2002), and they are most common during the dry season (NovemberFebruary), when northeasterly wind brings in air containing Saharan dust (Pinker et al., 2001, 2010). Higher dust load in late winter-early spring is also seen in Fig. 11a.

Among all of the sites included in the comparison, Ilorin shows the largest underestimation at both $340 \mathrm{~nm}$ and $500 \mathrm{~nm}\left(\mathrm{MB}_{340}=-0.33, \mathrm{MB}_{500}=-0.20\right)$, with a significantly stronger bias at $340 \mathrm{~nm}$. The correlation coefficient is similar at both wavelengths $\left(\mathrm{CC}_{340}=0.69, \mathrm{CC}_{500}=0.71\right)$. It seems there are two branches in the performance of the MACC AOD 340,500 data (Fig. 11b). This is seen in particular for AERONET $\mathrm{AOD}_{340,500}>1.5$. One branch is close to the $1: 1$ line, while the other shows a clear systematic underestimation. Interestingly, we found that for many of the large $\mathrm{AOD}_{340,500}$ values, the points belong to a single event of dust transport (Milton et al., 2008; Stanelle et al., 2010), seen at Ilorin on 10-15 March 2006. These days are marked with black circles in Fig. 11b. Note, that no data were available for 13 March 2006. The model did not capture the heavy aerosol load of the early days of the event (10-12 March), and therefore underestimated the $\mathrm{AOD}_{340,500}$ by a factor of $2-3$. For the later part of the event (14-15 March), on the other hand, the model is in good agreement with AERONET. Figure 11c furthermore shows that there is a fairly strong underestimation during the dry season (November-January) when $\mathrm{AOD}_{340}$ is high.

In order to understand this underestimation, we compared the DU+SS $\mathrm{AOD}_{550}$ of the model with the AERONET coarse mode $\mathrm{AOD}_{550}$, as for Thessaloniki. The model showed a fairly good agreement with the coarse mode $\mathrm{AOD}_{550}$ (not shown), indicating that the bias may have to do with small particles produced by biomass burning. Although Ilorin is a dust site, the difference between the total $\mathrm{AOD}_{340}$ and the coarse mode $\mathrm{AOD}_{550}$ further concludes that the fine mode aerosols make a significant contribution: roughly half of the $\mathrm{AOD}_{340}$ during the dry season comes from fine mode particles (not shown). The model seems to underpredict this fine mode fraction. On the other hand, the model agreement is slightly better during the period when small $\mathrm{AOD}_{340}$ values are observed, that is, from May to October (Fig. 11c). A possible explanation for this underestimation is that due to a high surface albedo, there is no MODIS satellite AOD data available over most of Sahara (Remer et al., 2005), so the MACC analysis mainly relies on the model parametrization of the dust sources (see Benedetti et al., 2009 Fig. 3c, for an illustration of MODIS data coverage, and Sect. 3.1). The MACC system might also miss localized sources of anthropogenic aerosols.

La Parguera is located on the southwest coast of the island of Puerto Rico. The ECMWF model shows, that the site is representative for sea salt, $\mathrm{SO}_{4}$ and dust aerosols mostly (Fig. 12a). The main dust outflow is from Sahara, as large quantities of African dust are carried over the Atlantic into the Caribbean region (Prospero and Lamb, 2003). The model exhibits a significant contribution by dust in summer, with a seasonal cycle with higher values in summer (Fig. 12a). Generally, the site is rather clean with most of measured $\mathrm{AOD}_{340,500}$ lying below 0.5 (Fig. 12b). The ECMWF model shows a good agreement with AERONET, and also captures the seasonal variation fairly well, however, occasional peaks (e.g., June-July 2004 and 2006) are clearly overestimated.

La Parguera shows somewhat similar scatter to Ilorin (Fig. 12b) and rather good correlation, which is higher at $500 \mathrm{~nm}\left(\mathrm{CC}_{500}=0.80\right)$ than at $340 \mathrm{~nm}\left(\mathrm{CC}_{340}=0.68\right)$. La Parguera, as well as El Arenosillo, exhibits small positive bias at $500 \mathrm{~nm}\left(\mathrm{MB}_{500}=0.05\right)$ and almost no systematic bias at $340 \mathrm{~nm}$. The difference between the MACC $\mathrm{AOD}_{340}$ and AERONET AOD 340 (Fig. 12c, blue line) stays roughly constant and close to zero throughout the year. However, the ratio (green line) shows underestimation in February-May, and is close to 1 for the rest of the months.

Solar Village, Saudi Arabia, is a continental site with a significant contribution of desert dust (Fig. 13a). Among all the sites included in this study, Solar Village exhibits the largest number of paired data points (Table 1), probably because of the stable and sunny weather conditions, providing continuous measurements over a long period. According to the long-term climatology over Arabian Peninsula, four different seasons can be defined (Kambezidis and Kaskaoutis, 2007; Smirnov et al., 2002): southwest monsoon (JuneSeptember), fall transition (October-November), northeast monsoon (December-March), and spring transition (AprilMay). Figure 13a shows that the highest observed monthly mean $\mathrm{AOD}_{550}$ values are seen in the spring transition. This is most likely due to high intensity of dust events during this period. Generally, the MACC AOD $_{550}$ is in a good agreement with AERONET AOD 550 . However, the model exhibits a broader peak than the observations, also extending into the 


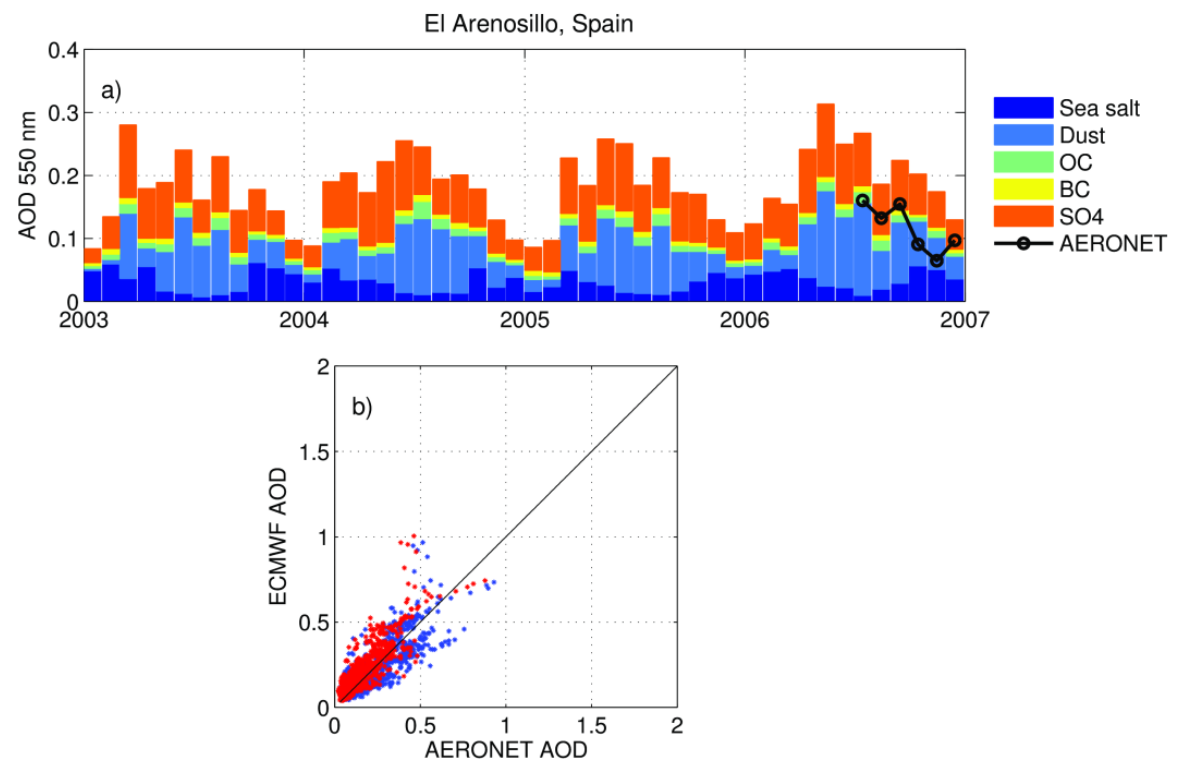

Fig. 10. Same as Fig. 2, but for El Arenosillo.
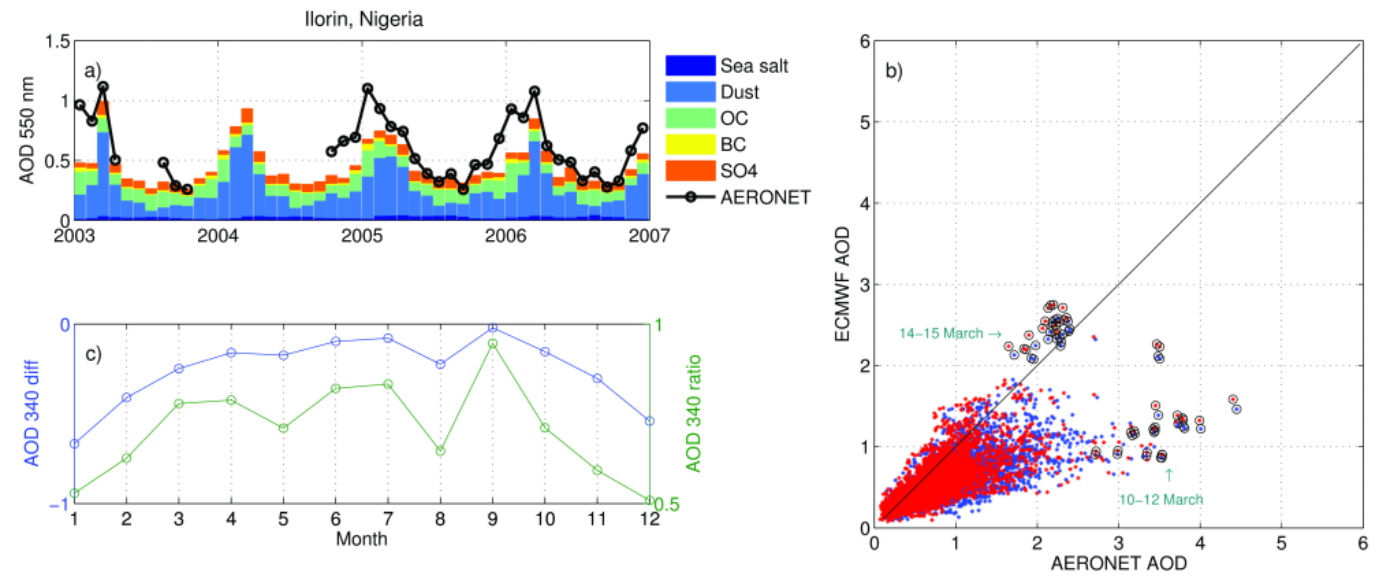

Fig. 11. Same as Fig. 1, but for Ilorin.

monsoon period. Overall, the model tends to somewhat overestimate the $\mathrm{AOD}_{550}$.

The MACC $\mathrm{AOD}_{340,500}$ values in Solar Village have a reasonable correlation of $\mathrm{CC}_{340}=0.68$ and $\mathrm{CC}_{500}=0.66$. A somewhat stronger overestimation is seen at $500 \mathrm{~nm}$ $\left(\mathrm{MB}_{500}=0.12\right)$ than at $340 \mathrm{~nm}\left(\mathrm{MB}_{340}=0.05\right)$, although for high aerosol loads $\left(\mathrm{AOD}_{340,500}>1\right)$, there is a clear systematic underestimation (Fig. 13b). The largest relative overestimation (Fig. 13c, green line) is seen for the two monsoon periods (June-September and December-March), when the aerosol load is generally low. Interestingly, this is a similar pattern as seen for Kanpur.

\subsection{Coarse and fine mode AOD}

Figure 14 presents a comparison between the MACC coarse and fine AOD at $550 \mathrm{~nm}$ and AERONET SDA retrievals by showing the relative mean bias (rMB) and the correlation coefficient (CC) for all stations included in the study. The modeled coarse mode $\mathrm{AOD}_{550}$ is defined as $\mathrm{SS}+\mathrm{DU}$ and fine mode $\mathrm{AOD}_{550}$ as $\mathrm{OC}+\mathrm{BC}+\mathrm{SO}_{4}$ and compared with measured coarse and fine mode $\mathrm{AOD}_{550}$ (as explained above for Thessaloniki). For most of the urban sites (blue squares), there is a clear underestimation in fine mode (empty squares) and overestimation in coarse mode AOD550 (colorfilled squares). The rMB for fine mode $\mathrm{AOD}_{550}$ averaged over all urban sites $\left(\mathrm{rMB}_{\mathrm{F}, \mathrm{urb}}\right)$ is -0.22 ; rMB for coarse mode $\mathrm{AOD}_{550}$ averaged over all urban sites $\left(\mathrm{rMB}_{\mathrm{C}, \mathrm{urb}}\right)$ is 

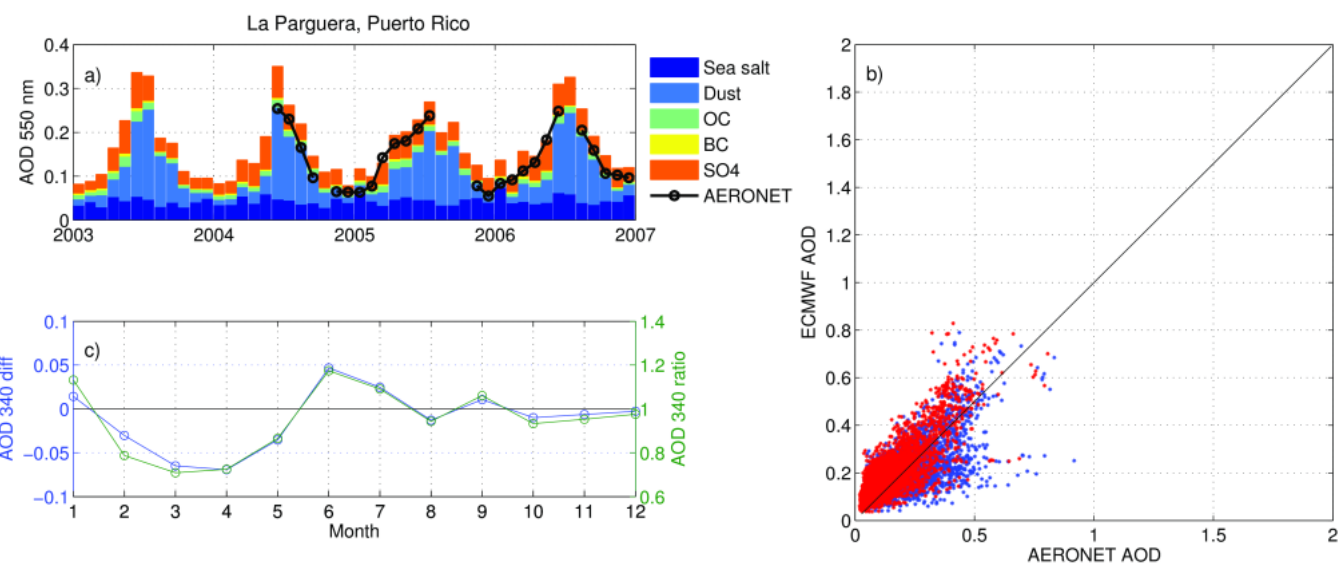

Fig. 12. Same as Fig. 2, but for La Parguera.
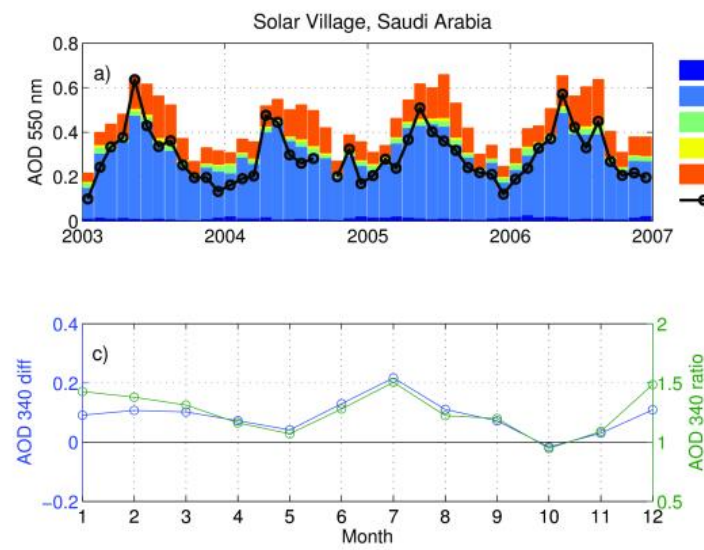
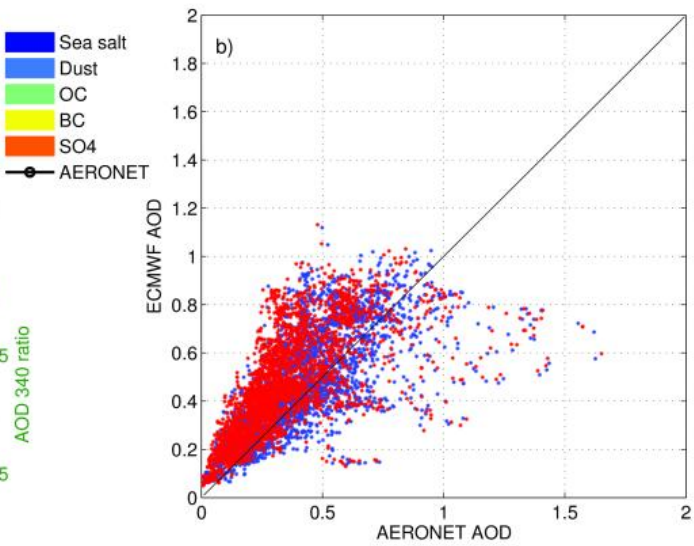

Fig. 13. Same as Fig. 2, but for Solar Village.

0.38 . This indicates that there are too many coarse mode and too few fine mode particles in the MACC system.

The dust particles (green triangles), in particular, play a significant role due to a higher contribution compare to sea salt (as visually seen from difference between light and dark blue color bars in Figs. 1-13a).

Similar behavior with an even larger difference between coarse and fine mode $\mathrm{AOD}_{550}$ is seen for biomass burning (red circles), where rMBs for fine and coarse mode $\mathrm{AOD}_{550}$ values averaged over all biomass burning sites are $\mathrm{rMB}_{\mathrm{F}, \text { biom }}=-0.22$ and $\mathrm{rMB}_{\mathrm{C}, \text { biom }}=0.64$, respectively. The dust sites exhibit a mixed behavior. For sites located close to dust sources (Capo Verde, El Arenosillo, Solar Village), the rMB is smaller for coarse mode than for fine mode AOD $_{550}$. However, the difference between coarse and fine mode is smaller than that seen for urban and biomass burning sites (seen from the length of the lines connecting an empty and color-filled shapes). La Parguera and Ilorin, on the other hand, show the opposite pattern with a larger rMB for fine mode. The overall underestimation in Ilorin is most likely due to the model parametrization of the dust sources included in the MACC system, since there is no aerosol retrieval from the MODIS radiances over all Sahara, and also from the fact that the MACC system might miss localized sources of anthropogenic aerosols.

For the sites where fine mode aerosols dominate (most of urban and biomass burning) the correlation averaged over all sites representing different areas is higher for fine mode $\mathrm{AOD}_{550}\left(\mathrm{CC}_{\mathrm{F} \text {, urb }}=0.59, \mathrm{CC}_{\mathrm{F} \text {,biom }}=0.89\right)$ than for coarse mode $\left(\mathrm{CC}_{\mathrm{C} \text {,urb }}=0.51, \mathrm{CC}_{\mathrm{C} \text {,biom }}=0.33\right)$. For the dust sites, the pattern is opposite with a higher correlation averaged over all dust sites being for coarse mode $\mathrm{AOD}_{550}\left(\mathrm{CC}_{\mathrm{C} \text {,dust }}=\right.$ $\left.0.81, \mathrm{CC}_{\mathrm{F} \text {,dust }}=0.57\right)$. Generally, the MACC system tends to overestimate the coarse mode $\mathrm{AOD}_{550}$ for most of the sites.

\subsection{Summary of all stations}

Figure 15 aims at summarizing the performance of the MACC $\mathrm{AOD}_{340,500}$ as compared to AERONET for all 


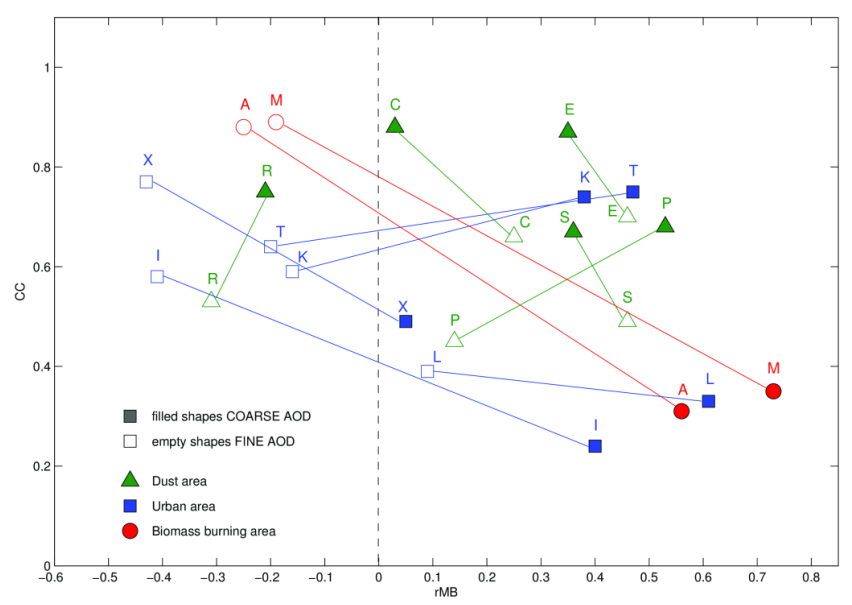

Fig. 14. Summary of aerosol validation statistics (rMB vs. CC ) for modeled coarse $(\mathrm{SS}+\mathrm{DU})$ and fine $\left(\mathrm{OC}+\mathrm{BC}+\mathrm{SO}_{4}\right)$ mode $\mathrm{AOD} 550$ compared to coarse and fine mode $\mathrm{AOD}_{550}$ from AERONET SDA. Filled shapes indicate coarse mode $\mathrm{AOD}_{550}$, whereas empty shapes indicate fine mode $\mathrm{AOD}_{550}$. Each point corresponds to a particular validation site: I - Ispra, M - Mongu, R - Ilorin, P - La Parguera, C - Capo Verde, K - Kanpur, E - El Arenosillo, S - Solar Village, A - Alta Floresta, L - La Jolla, T - Thessaloniki, X - Xianghe.

stations at both wavelengths (rMB vs. CC). There is a good correlation between modeled and measured $\mathrm{AOD}_{340,500}$ values in biomass burning sites, where $\mathrm{CC}$ is between 0.87 and 0.90 , and rather good in dust sites with $\mathrm{CC}$ between 0.68 and 0.87 , while the urban stations have the lowest correlation (Table 1). The correlation is similar at both $340 \mathrm{~nm}$ and $500 \mathrm{~nm}$, which is indicated by the fairly horizontal slopes of the lines, connecting each of the sites.

A major feature of the comparison is that the rMB is always smaller at $340 \mathrm{~nm}$ than at $500 \mathrm{~nm}$. The AOD at $500 \mathrm{~nm}$ averaged over all sites shows only a small systematic difference between the MACC data and the AERONET measurements, with a rMB of 0.02 . However, for the AOD at $340 \mathrm{~nm}$ the rMB is -0.2 . Most of the sites, that have a small $\mathrm{rMB}_{340,500}(-0.2-0.2)$, are dust dominated.

\section{Conclusions}

We compared the MACC hourly and monthly AOD data with AERONET measurements at 12 sites. Although our main emphasis was on AOD at UV wavelength, we also compared AOD at visible to examine possible wavelength-depended features.

For monthly AOD, the ECMWF model tends to follow the AERONET measurements rather well, also representing the yearly cycle correctly for each of the sites. Hourly values, however, exhibit a larger spread. In terms of correlation coefficient and relative mean bias, the best agreement between modeled and measured $\mathrm{AOD}_{340,500}$ values is seen in biomass

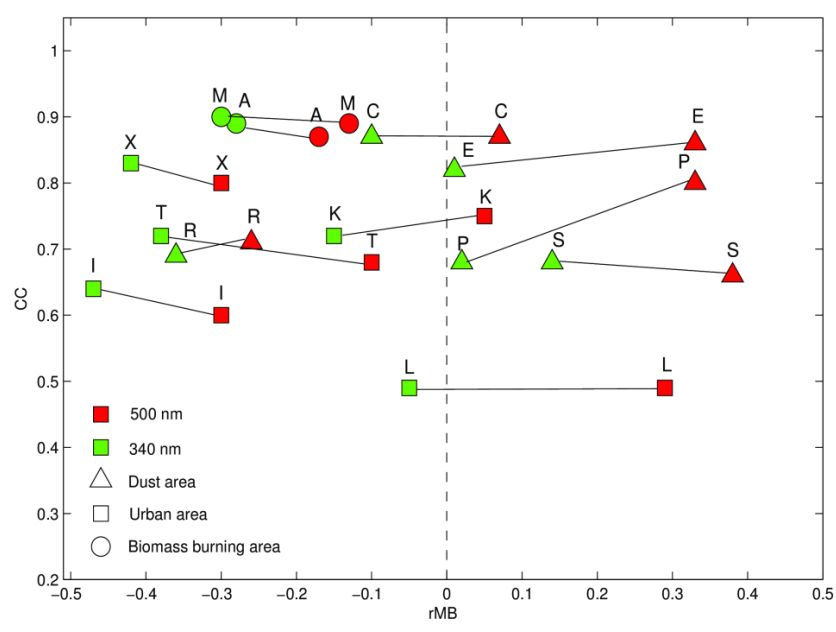

Fig. 15. Similar as Fig. 14, but for AOD at $340 \mathrm{~nm}$ (green) and $500 \mathrm{~nm}$ (red). Shape of points indicates different aerosol type: dust (triangle), urban (square), biomass burning (circle).

burning sites (Alta Floresta and Mongu). For these both sites, the ECMWF model is able to capture the burning season correctly, however, some occasional peaks are underestimated. The AOD for the dust sites included in our study also show rather good agreement with the AERONET observations, and the ECMWF model follows the seasonal pattern in the observed AOD fairly well. However, two (Capo Verde and El Arenosillo) of the five dust sites have less than one year of AERONET data available. The urban sites have the lowest correlation and largest bias.

Generally, a major feature of the model-measurements comparison is that the rMB is always smaller at $340 \mathrm{~nm}$ than at $500 \mathrm{~nm}$, and the difference between rMB at 340 and $500 \mathrm{~nm}$ averaged over all stations is approximately 0.2 . Thus, that indicates a rather strong wavelength-dependent feature of the performance of AOD in the MACC system.

Among all urban sites included in the comparison, Thessaloniki shows the largest difference between the performance of $\mathrm{AOD}_{340}$ and $\mathrm{AOD}_{500}$ (Fig. 5b). This is seen also in the Ångström exponent, which is unrealistically low in the model (as discussed above in Sect. 3.1), thus indicating this might have something to do with the overall combination of too little fine mode particles and too many coarse mode particles in the MACC system. This pattern is seen for almost all urban sites. We also analyzed the behavior of the Ångström exponent for the rest of the sites. The results show that the Ångström exponent in the MACC system is too low for all sites included in this study.

In addition, the wavelength dependent difference between MACC AOD and AERONET-based AOD may be partly, but to a smaller extent, explained by the wavelength-independent optical properties of different aerosol types assumed in the model. For instance, the same refractive index was assumed for $\mathrm{SO}_{4}$ and $\mathrm{OC}$. This assumption means that $\mathrm{OC}$ is not 
absorbing. However, recently there has been a growing evidence that some of the organic species are strongly absorbing at UV wavelengths.

The ECMWF model shows a somewhat similar behavior for two sites, Kanpur and Solar Village, which have a similar seasonal cycle driven by monsoons. The model tends to overestimate June-September months, which coincides with the monsoon period when particles are washed out from the atmosphere and the aerosol load is generally low. Thus, this may have to do with representation of rain and aerosol removal processes in the MACC system.

This study supports the results of Morcrette et al. (2009) and Mangold et al. (2011), however, their AOD comparisons, carried out at visible wavelength, were done more on specific cases and much shorter timescales. Our study included a longer time period and considered the AOD at both UV and visible wavelengths. This will be important for evaluating also the UV radiation in the ECMWF model.

Acknowledgements. This work has been supported by EU-project Monitoring Atmospheric Composition and Climate (MACC and MACC-II) under the European Union Seventh Framework Programme, grant agreement number 283576. We acknowledge the ECMWF organization scientists and AERONET Team for the production of the data used in this research effort.

Edited by: V.-H. Peuch

\section{References}

Akagi, S. K., Yokelson, R. J., Wiedinmyer, C., Alvarado, M. J., Reid, J. S., Karl, T., Crounse, J. D., and Wennberg, P. O.: Emission factors for open and domestic biomass burning for use in atmospheric models, Atmos. Chem. Phys., 11, 4039-4072, doi:10.5194/acp-11-4039-2011, 2011.

Andreae, M. O. and Crutzen, P. J.: Atmospheric aerosols: Biogeochemical sources and role in atmospheric chemistry, Science, 276, 1052-1058, 1997.

Benedetti, A., Morcrette, J.-J., Boucher, O., Dethof, A., Engelen, R. J., Fisher, M., Flentjes, H., Huneeus, N., Jones, L., Kaiser, J. W., Kinne, S., Mangold, A., Razinger, M., Simmons, A. J., Suttie, M., and the GEMS-AER team: Aerosol analysis and forecast in the ECMWF Integrated Forecast System: Data assimilation, ECMWF Technical Memorandum, 571, 23 pp., 2008.

Benedetti, A., Morcrette, J.-J., Boucher, O., Dethof, A., Engelen, R. J., Fisher, M., Flentjes, H., Huneeus, N., Jones, L., Kaiser, J. W., Kinne, S., Mangold, A., Razinger, M., Simmons, A. J., Suttie, M., and the GEMS-AER team: Aerosol analysis and forecast in the ECMWF Integrated Forecast System. Part II: Data assimilation, J. Geophys. Res., 114, D13205, doi:10.1029/2008JD011115, 2009.

Bevan, S. L., North, P. R. J., Grey, W. M. F., Los, S. O., and Plummer, S. E.: Impact of atmospheric aerosol from biomass burning on Amazon dry-season drought, J. Geophys. Res., 114, D09204, doi:10.1029/2008JD011112, 2009.

Chiapello, I., Prospero, J. M., Herman, J. R., and Hsu, N. C.: Detection of mineral dust over the North Atlantic Ocean and Africa with the Nimbus 7 TOMS, J. Geophys. Res., 104, 9277-9291, 1999.

Dee, D. and Uppala, S.: Variational bias correction in ERA-Interim, ECMWF Technical Memorandum, 575, 2008.

Dey, S. and Tripathi, S. N.: Aerosol direct radiative effects over Kanpur in the Indo-Gangetic basin, northern India: Long-term (2001-2005) observations and implications to regional climate, J. Geophys. Res., 113, D04212, doi:10.1029/2007JD009029, 2008.

Dubovik, O., Smirnov, A., Holben, B. N., King, M. D., Kaufman, Y. J., Eck, T. F., and Slutsker, I.: Accuracy assessments of aerosol optical properties retrieved from Aerosol Robotic Network (AERONET) Sun and sky radiance measurements, J. Geophys. Res., 105, 9791-9806, 2000.

Eck, T. F., Holben, B. N., Reid, J. S., Dubovik, O., Smirnov, A., O'Neill, N. T., Slutsker, I., and Kinne, S.: Wavelength dependence of the optical depth of biomass burning, urban, and desert dust aerosols, J. Geophys. Res., 104, 31333-31349, 1999.

Gobbi, G. P., Kaufman, Y. J., Koren, I., and Eck, T. F.: Classification of aerosol properties derived from AERONET direct sun data, Atmos. Chem. Phys., 7, 453-458, doi:10.5194/acp-7-453-2007, 2007.

Holben, B. N., Eck, T. F., Slutsker, I., Tanre, D., Buis, J. P., Setzer, A., Vermote, E., Reagan, J. A., Kaufman, Y. J., Nakajima, T., Lavenu, F., Jankowiak, I., and Smirnov, A.: AERONET - A federated instrument network and data archive for aerosol characterization, Remote Sens. Environ., 66, 1-16, 1998.

Hsu, N. C., Tsay, S.-C., King, M., and Herman, J. R.: Deep Blue retrievals of Asian aerosol properties during ACE-Asia, IEEE Trans., Geosci. Remote Sens., 44, 3180-3195, 2006.

Huneeus, N. and Boucher, O.: One-dimensional variational retrieval of aerosol extinction coefficient from synthetic LIDAR and radiometric measurements, J. Geophys. Res., 112, D14303, doi:10.1029/2006JD007625, 2007.

Kaiser, J. W., Heil, A., Andreae, M. O., Benedetti, A., Chubarova, N., Jones, L., Morcrette, J.-J., Razinger, M., Schultz, M. G., Suttie, M., and van der Werf, G. R.: Biomass burning emissions estimated with a global fire assimilation system based on observed fire radiative power, Biogeosciences, 9, 527-554, doi:10.5194/bg-9-527-2012, 2012.

Kambezidis, H. D. and Kaskaoutis, D. G.: Arosol climatology over four AERONET sites: an overview, Atmos. Environ., 42, 18921906, 2008.

Kazadzis, S., Bais, A., Amiridis, V., Balis, D., Meleti, C., Kouremeti, N., Zerefos, C. S., Rapsomanikis, S., Petrakakis, M., Kelesis, A., Tzoumaka, P., and Kelektsoglou, K.: Nine years of UV aerosol optical depth measurements at Thessaloniki, Greece, Atmos. Chem. Phys., 7, 2091-2101, doi:10.5194/acp-7-20912007, 2007.

Koren, I., Kaufman, Y. J., Washington, R., Todd, M. C., Rudich, Y., Vanderlei Martins, J., and Rosenfeld, D.: The Bodele depression: a single spot in the Sahara that provides most of the mineral dust to the Amazon forest, Environ. Res. Lett., 1, 014005, doi:10.1088/1748-9326/1/1/014005, 2006.

Koren, I., Remer, L. A., and Longo, K.: Reversal of trend of biomass burning in the Amazon, Geophys. Res. Lett., 34, L20404, doi:10.1029/2007GL031530, 2007.

Levy, R. C., Remer, L. A., and Dubovik, O.: Global aerosol optical properties and application to Moderate Resolution Imaging 
Spectroradiometer aerosol retrieval over land, J. Geophys. Res.Atmos., 112, D13210, doi:10.1029/2006JD007815, 2007a.

Levy, R. C., Remer, L. A., Mattoo, S., Vermote, E. F., and Kaufman, Y. J.: Second-generation operational algorithm: Retrieval of aerosol properties over land from inversion of Moderate Resolution Imaging Spectroradiometer spectral reflectance, J. Geoph. Res.-Atmos., 112, D13211, doi:10.1029/2006JD007811, 2007b.

Li, Z., Chen, H., Cribb, M., Dickerson, R., Holben, B., Li, C., Lu, D., Luo, Y., Maring, H., Shi, G., Tsay, S.-C., Wang, P., Wang, Y., Xia, X., Zheng, Y., Yuan, T., and Zhao, F.: Aerosol optical properties and its radiative effects in northern China, J. Geophys. Res., 112, D22S01, doi:10.1029/2006JD007382, 2007.

Mangold, A., De Backer, H., De Paepe, B., Dewitte, S., Chiapello, I., Derimian, Y., Kacenelenbogen, M., Leon, J.-F., Huneeus, N., Schulz, M., Ceburnis, D., O’Dowd, C. D., Flentje, H., Kinne, S., Benedetti, A., Morcrette, J. J., and Boucher, O.: Aerosol analysis and forecast in the ECMWF Integrated Forecast System. Part IV: Evaluation by means of case studies, J. Geophys. Res, 116, D03302, doi:10.1029/2010JD014864, 2011.

Marengo, J. A., Nobre, C. A., Tomasella, J., Oyama, M. D., de Oliveira, G. S., de Oliveira, R., Camargo, H., Alves, M. L., and Brown, F. I.: The drought of Amazonia in 2005, J. Climate, 21, 495-516, 2008.

Milton, S. F., Greed, G., Brooks, M. E., Haywood, J., Johnson, B., Allan, R. P., Slingo, A., and Grey, W. M.: Modeled and observed atmospheric radiation balance during the West African dry season: Role of mineral dust, biomass burning aerosol, and surface albedo, J. Geophys. Res., 113, D00C02, doi:10.1029/2007JD009741, 2008.

Morcrette, J. J. and Arola, A.: A Processor to get UV-B and UV-A Radiation Products in/from the ECMWF IFS, ECMWF Technical Memorandum, 528, 2007.

Morcrette, J. J., Boucher, O., Jones, L., Salmond, D., Bechtold, P., Beljaars, A., Benedetti, A., Bonet, A., Kaiser, J.W., Razinger, M., Schulz, M., Serrar, S., Simmons, A. J., Sofiev, M., Suttie, M., Tompkins, A. M., and Untch, A.: Aerosol analysis and forecast in the European Centre for Medium-RangeWeather Forecasts Integrated Forecast System: Forward modeling, J. Geophys. Res. Atmos., 114, D06206, doi:10.1029/2008JD011235, 2009.

Morcrette, J. J., Benedetti, A., Jones, L., Kaiser, J. W., Razinger, M., and Suttie, M.: Prognostic Aerosols in the ECMWF IFS: MACC vs. GEMS Aerosols, ECMWF Technical Memorandum, 659, 2011.

Muhs, D. R., Budahn, J., Reheis, M., Beann, J., Skipp, G., and Fisher, E.: Airborne dust transport to the eastern Pacific Ocean off southern California: Evidence from San Clemente Island, J. Geophys. Res., 112, D13203, doi:10.1029/2006JD007577, 2007.

Pinker, R. T., Pandithurai, G., Holben, B. N., Dubovik, O., and Aro, T. O.: A dust outbreak episode in sub-Sahel west Africa, J. Geophys. Res., 106, 22923-22930, 2001.

Pinker, R. T., Liu, H., Osborne, S. R., and Akoshile, C.: Radiative effects of aerosols in sub Sahel Africa: Dust and biomass burning, J. Geophys. Res., 115, D15205, doi:10.1029/2009JD013335, 2010.

Prospero, J. M. and Lamb, P. J.: African droughts and dust transport to the Caribbean: Climate change implications, Science, 302, 1024-1027, 2003.
Prospero, J., Ginoux, P., Torres, O., Nicholson, S., and Gill, T.: Environmental characterization of global sources of atmospheric soil dust identified with the Nimbus-7 total ozone mapping spectrometer (TOMS) absorbing aerosols product, Rev. Geophys., 40, 1002, doi:10.1029/2000RG000095, 2002.

Remer, L. A., Kaufman, Y. J., Tanré, D., Matoo, S., Chu, D. A., Martins, J. V., Li, R. R., Ichoku, C., Levy, R. C., Kleidman, R. G., Eck, T. F., Vermote, E., and Holben B. N.: The MODIS aerosol algorithm, products and validation, J. Atmos. Sci., 62, 947-973, 2005.

Remer, L. A., Kleidman, R. G., Levy, R. C., Kaufman, Y. J., Tanré, D., Matoo, S., Martins, J. V., Ichoku, C., Koren, I., Yu, H., and Holben B. N.: Global aerosol climatology from the MODIS satellite sensors, J. Geophys. Res.-Atmos., 113, D14S07, doi:10.1029/2007JD009661, 2008.

Smirnov, A., Holben, B. N., Dubovik, O., O’Neill, N. T., Eck, T. F., Westphal, D. L., Goroch, A. K., Pietras, C., and Slutsker, I.: Atmospheric Aerosol Optical Properties in the Persian Gulf, J. Atmos. Sci., 59, 620-634, 2002.

Stanelle, T., Vogel, B., Vogel, H., Bäumer, D., and Kottmeier, C.: Feedback between dust particles and atmospheric processes over West Africa during dust episodes in March 2006 and June 2007, Atmos. Chem. Phys., 10, 10771-10788, doi:10.5194/acp10-10771-2010, 2010.

Todd, M. C., Martins, V., Washington, R., Lizcano, G., Dubovik, O., M'Bainayel, S., and Engelstaedter, S.: Mineral dust emission from the Bodele Depression, Chad during BoDEx 2005, J. Geophys. Res., 112, D06207, doi:10.1029/2006JD007170, 2007.

Toledano, C., Cachorro, V. E., Berjon, A., de Frutos, A. M., Sorribas, M., de la Morena, B. A., and Goloub, P.: Aerosol optical depth and Angstrom exponent climatology at El Arenosillo AERONET site (Huelva, Spain), Q. J. Roy. Meteorol. Soc., 133, 795-807, doi:10.1002/qj.54, 2007a.

Toledano, C., Cachorro, V. E., de Frutos, A. M., Sorribas, M., Prats, N., and de la Morena, B.: Inventory of African desert dust events over the southwestern Iberian Peninsula in 2000-2005 with an AERONET Cimel Sun photometer, J. Geophys. Res.-Atmos., 112, D21201, doi:10.1029/2006JD008307, 2007 b.

Xue, Y., Xu, H., Mei, L., Guang, J., Guo, J., Li, Y., Hou, T., Li, C., Yang, L., and He, X.: Merging aerosol optical depth data from multiple satellite missions to view agricultural biomass burning in Central and East China, Atmos. Chem. Phys. Discuss., 12, 10461-10492, doi:10.5194/acpd-12-10461-2012, 2012.

Zeng, N., Yoon, J. H., Marengo, J. A., Subramaniam, A., Nobre, C. A., Mariotti, A., and Neelin, J. D.: Causes and impacts of the 2005 Amazon drought, Environ. Res. Lett., 3, 014002, doi:10.1088/1748-9326/3/1/014002, 2008.

Zhang, J. and Reid, J. S.: MODIS aerosol product analysis for data assimilation: Assessment of over-ocean level 2 aerosol optical thickness retrievals, J. Geophys. Res., 111, D22207, doi:10.1029/2005JD006898, 2006. 